\title{
3. Parliamentary Scrutiny of the Australian Public Service
}

\author{
Derek Drinkwater
}

\section{Introduction}

After a century of industrialisation and urbanisation, and a commensurate rise in state power, Australia is experiencing 'a major reconceptualisation of the role of government' (Nethercote 2003, p. 12). The need for Parliament to address such change had arisen as early as 1950, when Professor Wolfgang Friedmann called for 'a re-consideration of the problem of parliamentary control' over the increasingly pervasive activity and influence of governments (Friedmann 1950, p. 27). Ambitious initiatives to this end were introduced in the 1960s, with the past three decades witnessing the growth of a complex 'web of parliamentary scrutiny' of all aspects of governance, especially public administration (Cole 1980, p. 174). Today, Parliament's capacity to scrutinise the performance of ministers and public servants outside the chamber is of a similar order to its legislative power. This is a welcome development, which provides opportunities for identifying ministerial neglect and bureaucratic maladministration. It is also important in reducing their incidence. As Walter Bagehot put it: 'All checks are valuable, not in proportion to the vices which they discover, but in proportion to the vices which they prevent' (Bagehot 1974, p. 42). The purpose of this chapter is to determine whether this web has been as effective as its designers intended in ensuring the accountability to Parliament of Australia's main non-political institution of government, the Australian public service (APS) (the Commonwealth public service (CPS) 1901-73 when it received its present name).

The vehicles for enhanced scrutiny introduced from the early 1970s expanded parliamentary committee arrangements, improved financial and auditing practices, more rigorous budget reporting procedures — transformed the means of evaluating public administration at the federal level. The earliest manifestation of parliamentary scrutiny of public service operations occurred in the Senate and the House of Representatives after federation in 1901. With some exceptions - chiefly, the activities of two parliamentary joint statutory committees - the Joint Committee on Public Accounts and Audit (1913-32, 1952-2011) and Public Works (1913-2011), only a modest degree of committee scrutiny took place during Parliament's first six decades. Wide-ranging scrutiny by committees across the whole spectrum of government activity did not become 
commonplace until the creation of a formidable Senate committee system in 1970. This event 'revolutionised the Parliament as a whole' (Reid and Forrest 1989, p. 375).

The importance accorded to the work of the Auditor-General, and to the requirement that departments and other Commonwealth agencies report annually on their activities to Parliament, fluctuated last century. It was only during the 1980s that these became major elements in parliamentary scrutiny. Government's growing complexity from the late 1960s also spawned new administrative machinery and relationships whose implications for governance are only now seriously emerging (and demanding to be addressed). Some of these raise questions central to scrutiny. They include the position of ministerial staff in Australian government-APS interchange; the obligations and responsibilities of public servants and ministerial advisers, especially in relation to parliamentary committees; and the increased exposure of APS employees to scrutiny in an atmosphere in which they, even more than ministerial staff and politicians, are called upon increasingly to shoulder accountability responsibilities that would previously have been borne by their ministerial chiefs.

Parliamentary scrutiny is more than 'the assertion of the supremacy of Parliament over the Executive Government in money matters' (Odgers 1979, p. 23). Ideally, its remit extends to monitoring administrative efficiency and influencing spending priorities and policies (HRSCE 1979, p. 11). As Stanley Bach has argued, 'if the process of scrutiny of legislation or administration did not change policy outcomes from time to time, it would serve no serious governmental function' (Bach 2003, p. 154). There are now 'numerous structures, processes and systems' which facilitate financial and administrative scrutiny (Baxter 2003, p. 65). Parliamentary scrutiny, like accountability, has become multidimensional, "not a "thing" in itself, but a set of relationships through which political and bureaucratic actors must account for their integrity and their performance' (Stewart 2002, p. 69).

The advent of a Senate committee system and the House of Representatives Standing Committee on Expenditure (1976) strengthened scrutiny but did not displace the traditional apparatus of oversight and control. The problem remained of how best to bring information before Parliament in ways that would assist Senators and MPs to exercise their investigatory authority over standards of administrative performance and government financial management. In the mid1970s this prompted the authors of one major review of public administration to call for improvements and refinements to Parliament's scrutiny function in several areas. This chapter examines these in turn: the chamber vehicles of Question Time (or Questions without Notice), Questions on Notice, and Matters of Public Importance (these counting as one category); committee activity; the work of the Australian National Audit Office (ANAO); budget evaluation and 
appropriation processes; and the accountability of ministerial advisers and public servants within the framework of parliamentary privilege (RCAGA 1976, pp. 108-113).

However, throughout the 1970s and 1980s it became clear that, although Parliament was no 'cipher in the sphere of public accountability', it still faced many obstacles in achieving 'the smallest kinetic effect upon the Public Service' (Reid 1981, p. 133). One commentator, in proffering reasons for this, complained that 'parliament's scrutiny of government administration has been hindered by secrecy, public service anonymity, limited resources and the burgeoning of inscrutable statutory bodies' (Indyk 1980, p. 93). Two decades on, it remained generally accepted that the Senate's 'key role' of scrutiny continued to be essential to a healthy Australian democracy (Faulkner 2003, p. 4). Much the same can be said of the House of Representatives, although its contribution to this process is often underestimated. Simplistic diagnoses based on portrayals of the Senate as Saint George and the executive (buttressed by the House of Representatives) as the dragon to be slain do little to improve public and specialist understanding of the situation. More detailed examination of the parliamentary record would assist in addressing such misconceptions. Initial research of this kind suggests that, today's high volume of parliamentary business notwithstanding, Australians could be better served by their elected representatives, whose primary tasks include ensuring more effective scrutiny of the APS.

In Australia (as in a number of other parliamentary democracies) such trends are adversely affecting the main institutions of governance, namely, the Parliament and the APS (Mulgan 2003, p. 57). The solution to this problem lies in understanding its deep-seated origins, rather than in resorting to the well-rehearsed mantra of the executive as the chief impediment to a degree of parliamentary scrutiny worthy of the name. It is also to be found in better methods of evaluating and assessing public administration in the federal sphere. An important basis for such innovation would be more trenchant research into the parliamentary sources themselves in understanding past developments, testing widely held hypotheses, and developing new approaches. While such calls are made periodically (usually in relation to estimates activity) (Uhr 1990, p. 83), the paucity of detailed studies of parliamentary history renders this a recurring problem. However, recognition of the need for intensive and sustained inquiry into parliamentary scrutiny is growing. A persuasive call to this effect was made by Colleen Lewis and Ken Coghill in their article, 'Surveying Research on Parliament and Parliamentary Oversight of the Public Sector' (Lewis and Coghill 2005).

Since the then Howard government achieved an (admittedly narrow) Senate majority following the 9 October 2004 general election, there has been an increase 
in discussions about parliamentary oversight procedures. The implications of this for parliamentary scrutiny of the APS have been the subject of considerable debate. Some Senators and MPs have maintained that the machinery of scrutiny in both houses remains as effective as ever. Others are much less sanguine, pointing to a notable decline in the number of sitting days (the Senate during the 41st Parliament had the then lowest number of sitting days for 50 years, the starting point of a trend of significantly lower allocated sitting days for the Senate); the deleterious effects of departmental restructuring on the Senate estimates process (for instance, difficulties in adequately examining the activities of the Department of Human Services which, for estimates purposes, for some time were spread across the Department of Finance and Administration and other agencies); an increasing tendency for the government to resort to classifying material as 'commercial-in-confidence' in order to avoid or delay providing information on APS administration; fewer so-called 'spillover' days for debate; and growing, deliberately imposed time and resources constraints on the consideration of legislation (National Institute for Governance 2005a).

The Rudd-led Australian Labor Party (ALP) government elected in 2007 was slow to act on parliamentary reform. However, in 2010, the first hung Parliament since 1941 forced the ALP and Coalition parties to implement meaningful parliamentary reform, most notably to Question Time due to the pressure of independent MPs. The independent MPs insisted on securing an agreement on parliamentary reform before any agreement on forming a government. As a result, changes to the standing orders, Question Time, House of Representatives committees and Private Members' Bills were negotiated and agreed to by both the ALP and Coalition parties. While the changes to parliamentary scrutiny procedures in the standing orders have been implemented, the spirit of the reforms were almost immediately abandoned as the Coalition reneged on much of the 'in principle' reforms outlined in 'Agreement for a Better Parliament: Parliamentary reform' (House of Representatives 2010). This fact is reflected in the continuing poor behaviour of MPs during Question Time and the institution's enduring low standing in the community. In this context it is difficult to assess the reform's long-term impact on the Parliament.

\section{The role of Question Time, Questions on Notice, and Matters of Public Importance in legislative scrutiny}

Question Time and committee activity are the best known features of the parliamentary machinery. According to received specialist and public opinion, Question Time is the one most abused by Senators and MPs. This is a longstanding 
concern. Even parliamentarians have variously described Question Time (the period set down for Questions without Notice) as a 'propaganda forum', a 'blood sport' and 'an absolute farce' (CPD (Commonwealth Parliamentary Debates) Senate, 9 September 1971, p. 583; 25 October 1973, p. 1451; 21 May 1990, p. 608). The most frequently aired complaint concerns the 'Dorothy Dixer' - a prearranged question addressed to the Prime Minister or a Minister by a government MP in order to show the administration in a favourable light (CPD, House of Representatives, 22 April 1971, pp. 1864-1865; 14 March 1973, pp. 538, 546; 13 October 1983, pp. 1702-1703).

Question Time has long been a point of debate and anxiety for parliamentarians, academics and citizens. Previously, the customary length of Question Time (approximately 45 minutes) was often criticised as being too short; yet parliamentarians repeatedly resisted proposals to extend its length beyond 45 minutes (CPD, Senate, 25 October 1972, pp. 1883-1889). Criticism of governments who curtail Question Time for perceived political purposes is invariably severe. In October 1993, for example, one Senator protested against the Prime Minister's decision the day before to terminate Question Time (in the House of Representatives) after only 25 minutes, allegedly to save the Minister for Finance further political embarrassment (CPD, 6 October 1993, p. 1727). More infamous still was the conclusion of Question Time after a single question by Prime Minster Julia Gillard following a failed attempt to censure the Prime Minister and the government by the leader of the opposition (CPD, House of Representatives, 24 August 2011, p. 9216). The practice of ministers reading prepared (and lengthy) answers to questions, which absorbs valuable time and reduces opportunities for participation by non-ministers, has regularly been deplored (CPD, House of Representatives, 1 May 1963, p. 926; 18 October 1983, pp. 1811-1812; 17 October 1991, p. 2174). Another common objection relates to the absence or inadequacy of procedures designed to prevent evasive replies to questions (CPD, Senate, 24 May 1972, p. 2025).

The degeneration of Question Time into a set-piece opportunity for tactical stroke and counter-stroke, in which replies to questions are constantly turned into matters for debate, has frequently drawn comment (CPD, Senate, 11 October 1973, p. 1155; 13 November 1990, pp. 3970-3971). In 1990, one opposition Senator insisted that, although some latitude for delay in protecting the government by such means was acceptable, when this became regular and systematic the situation was untenable (CPD, Senate, 21 May 1990, p. 608). Nevertheless, little improvement in Senators' or MPs' behaviour followed during the 1990s, or in the wake of the 2010 reforms.

Some prime ministers (and a long-serving party leader, W. G. Hayden) have put forward ambitious reform proposals for Question Time. Prime Minister E. G. Whitlam advocated changes to the Standing Orders whereby Senate 
ministers could be rostered to answer Questions without Notice in the House of Representatives (and vice versa) (CPD, House of Representatives, 30 August 1973, p. 632). On 25 February 1982, his successor as party leader, Bill Hayden, proposed that the following six-part motion be referred to the Standing Orders Committee (it was so referred, though the matters were never implemented):

The standing orders and practices which govern the conduct of Question Time, taking particular account of:

1. The definition of relevancy in answers to questions and the setting out of criteria to define relevancy in accordance with legal definition.

2. Length of answers to be subject to a time limit.

3. The need for clearer definition in the standing orders about the practice in relation to supplementary questions.

4. Senators who are ministers to attend the house to answer questions.

5. The appropriateness of setting down specified sitting days as days on which questions will be directed to ministers about particular departments.

6. Question Time to be a minimum of 45 minutes (CPD, House of Representatives, 25 February 1982, pp. 595-598).

Other suggested changes have included the proposal that Question Time continue each day until 28 questions are asked and answered (CPD, House of Representatives, 27 September 1993, p. 1158).

A survey of the Commonwealth Parliamentary Debates for both houses between 1964 and 2010 reveals Senators and MPs to have had a recurring interest in certain aspects of APS operations. All were frequently the subject of Questions without Notice. They included (principally) the size and costs of running the organisation; the recruitment and training of staff (from in-service training to cadetships to graduate programs); the employment of people with disability; the recruitment and development of Indigenous Australians; the role, numbers and level of seniority of women and the elimination of discrimination against them (from the abolition of the 'marriage bar' to the implementation of the 'equal pay for equal work' principle to affirmative action initiatives); public sector leave provisions and superannuation arrangements; the health of employees (for example, the high incidence of tenosynovitis and repetitive strain injury during the mid-1980s); public servants' membership of and/or dealings with trade unions; the freedom of expression allowed to public sector staff; the part played by ministerial advisers in APS-executive interaction (an issue first raised seriously in 1973); the activities and influence of the Public Service Board (abolished in 1987) and, later, those of the Department of the Prime Minister and Cabinet; the annual reports of departments and other government agencies; financial 
management reforms (notably, the changes introduced from the early 1980s); the new structures and practices consequent upon public service devolution in the late 1990s; and the steady growth in office automation culminating in the dominance of the internet and IT technologies over administrative processes and research methodologies.

Judgements regarding the role of Question Time in legislative scrutiny have been remarkably similar over the years. While Ken Baxter over-optimistically calls it 'a lethal weapon in the armoury of good governance' (Baxter 2003, p. 65), G. S. Reid and Martyn Forrest's description of it as 'a device for executive advantage in both houses' (Reid and Forrest 1989, p. 367) better reflects majority opinion on the subject. Hansard transcripts, committee report recommendations, and political party platforms of the 1990s and early 2000s, point to continuing concerns.

This has been the case in each house. Between 1989 and 1992, for example, 6,814 Questions without Notice were asked in the Senate and 2,595 in the House of Representatives. The latter's Standing Committee on Procedure, in its report 'About Time' (HRSCP 1993), sought to counter the decline in the number of questions being asked during Question Time. The Committee observed that the average number of questions put on each occasion had almost halved between 1976 and 1992 (from 19.3 to 10.8), despite the longer Question Time (a maximum of 62.8 minutes compared with a minimum of 48.5 minutes). By 1993, both figures had fallen further - 10.6 questions during a period of 48.2 minutes. The committee's suggested solution was a longer Question Time and the requirement that a minimum number of questions be asked. However, it concluded that procedural reform alone would not be enough; a different approach was needed by the government and the opposition to the issue of Questions without Notice (HRSCP 1993, pp. xi, 2, 21). In April 2007, the ALP promised that, if successful at the forthcoming election, it would require the attendance of all ministers during Question Time and ensure that all questions were properly answered (ALP 2007, p. 180). However, the commitment the party made in 2004 (in its 'Machinery of Government' policy) to work for a better Parliament-executive balance through Question Time reform was not part of its 2007 policy agenda (Latham and Faulkner 2004, p. 9).

Not surprisingly, the Liberal-National Party Coalition government argued that there was no need for reform, the Prime Minister, John Howard, defending his administration's approach to Question Time in comparison with that of his two ALP predecessors, R. J. L. ('Bob') Hawke and Paul Keating. He described the institution of Question Time, not as a courtesy extended to the House by the executive, but as an essential element of executive accountability to Parliament. 'In the end', Howard emphasised, 'the real determinant of the accountability of 
a government and of a prime minister is their willingness to front up here day after day to answer questions' (CPD, House of Representatives, 27 June 2002, p. 4602).

During the 13 years of the Hawke and Keating administrations (between March 1983 and March 1996), 9,248 questions (an average of 711 questions annually) were asked during Question Time in the House of Representatives, and 19,646 questions in the Senate (an annual average of 1,511 questions). Between the Howard government's election in March 1996 and November 2007 - a parliamentary period of 12 years - 14,150 Questions without Notice were asked in the House of Representatives (an average of 1,179 annually), and a total of 15,211 in the Senate (a yearly average of 1,170 questions). Since 1983, on the basis of the average number of questions asked each year, scrutiny during Question Time has clearly been more vigorous in the Senate under ALP governments and more marked in the House of Representatives under Coalition governments. ${ }^{1}$ Although, in terms of the number of questions asked, Senate Question Time needs to become more robust in comparison with the years 1983-96, these findings provide a revealing contrast to the prevalent perception of a weak House of Representatives Question Time system under constant attack from the executive.

\section{Changes since 2007}

The election of the Rudd ALP government on 24 November 2007 resulted in modest reforms of Question Time in the Senate. In September 2008, the Senate Standing Committee on Procedure proposed changes to the nature of Question Time:

1. All primary questions to be placed on a Question Time Notice Paper by $11 \mathrm{am}$.

2. Up to 6 supplementary questions following each primary question.

3. Up to 2 minutes for an answer to each primary or supplementary question.

4. Answers to be directly relevant to each question.

The effect of these changes would have resulted in government agencies spending less time preparing briefs for questions that may arise during Questions without Notice. Moreover, these changes would have also facilitated greater engagement across the chamber and between multiple parties. However, these bold reforms

\footnotetext{
1 In only nine years during 1964-2011 did the number of questions asked in the House of Representatives exceed the number asked in the Senate $(1964,1965,1966,1967,1969,2005,2006,2007$ and 2008).
} 
were not adopted by the Senate. Instead, as outlined by the Senate Standing Committee on Procedure in its third report, the upper chamber held a two-week trial of the following during the last two sitting weeks of 2008 :

1. no notice to be given of questions, as at present;

2. primary questions to be limited to one minute and the answers to them to two minutes;

3. two supplementary questions to be allowed to the questioner;

4. supplementary questions and the answers to them to be limited to one minute each;

5. answers to be required to be directly relevant to each question, as in the original proposal.

As Senator Faulkner outlined, the effect of these changes was ultimately rather cosmetic, increasing the total amount of time for the questioner by one minute and reducing the time for answers by one minute (CPD, Senate, 13 November 2008, pp. 26-27). These temporary procedures have not been adopted permanently, but were extended three times and are still in effect at the time of writing.

In the House of Representatives, the election of the first hung parliament since 1941 forced the issue of parliamentary reform upon all major parties. The independent MPs, spearheaded by Rob Oakeshott, negotiated an overhaul of parliamentary standing orders and procedures before agreeing to support either party to form a government (House of Representatives 2010). The reforms were aimed at making changes to the standing orders of the House of Representatives; they also sought to change the culture of parliamentary procedure. Three of the reforms called for by Bill Hayden were addressed or implemented. On 29 September 2010, amendments to the standing orders were introduced, placing formal time limits on questions of 45 seconds and four minutes for answers. On 8 February 2012, the time limits were further reduced on questions to 30 seconds and on answers to three minutes (CPD, House of Representatives, 8 February 2012, pp. 10-11). While a definition of 'relevancy' was not included in the parliamentary reforms, the standing orders were amended such that answers 'must be directly relevant to the question', and that 'a point of order regarding relevance may be taken only once in response to each answer' (CPD, House of Representatives, 29 September 2011, p. 123).

Additionally, the agreement called for the opposition to be given the opportunity to ask one supplementary question during each Question Time. While the provision for supplementary questions already existed within the standing orders, the privilege had not been used since 1998. The reforms provided the opportunity for the reinterpretation of this privilege and this process has continued with the introduction of an opportunity for a second supplementary 
question in 2012, on a trial basis. Finally, the agreement called for Question Time to end no later than $3.30 \mathrm{pm}$, thereby allowing time for 20 questions to be answered (House of Representatives 2010). The implementation of an outer time limit could be interpreted as a reaction against the former Prime Minister Kevin Rudd's regular practice of allowing Question Time to continue beyond $3.30 \mathrm{pm}$ and even past $4 \mathrm{pm}$. On the other hand, Question Time has twice ended after only one question was asked (CPD, House of Representatives, 24 August 2011, p. 9216; 24 November 2011, p. 2011). While there has been criticism of these short Question Times, no minimum question threshold or time limit has been raised in the Parliament.

After more than a year in operation, the reforms to parliamentary procedures have produced modest improvements. The changes to time limits on Questions without Notice have modestly reduced the length of questions only by seconds. The changes have been made more successful by reducing the length of answers by ministers to government questions from an average of four minutes and 52 seconds to two minutes and 23 seconds. The opposition has made good use of the opportunity to ask supplementary questions, asking 64 supplementary questions in the period until October 2011 (Parliamentary Library 2011, p. 6). However, since these statistics were recorded in 2011, the opposition has on only five occasions not asked supplementary questions during Question Times (Parliamentary Library 2011, p. 9). Enforcing relevance remains a vexed problem, ultimately relying on the willingness of the Speaker to enforce a ruling. Yet, Speaker Peter Slipper took the unprecedented step of removing the call from Prime Minister Julia Gillard after several warnings of failing to be relevant (CPD, House of Representatives, 28 February 2012, pp. 1-2). However, Speaker Slipper's stance arose as a result of the finely balanced numbers of the minority Parliament and because it suited the political position of the government. It is unlikely that future speakers, conventionally supplied by the government, would have this capacity and security in their position to assert their will over ministers and prime ministers.

Nevertheless, commentators continue to lament the supposedly parlous state of Question Time. Coghill attributes this chiefly to the 'ridiculous' rules governing its operation and to ministers' prolonged 'preambles' to answers. He stigmatises this development as a 'peculiarly Australian problem', and proposes amended procedures designed to ensure that questions are answered, except where the national interest may be adversely affected (such a determination to be made by the presiding officer of the house concerned, namely, the President of the Senate or the Speaker of the House of Representatives, respectively). In addition, in instances where the Minister is genuinely unable to reply, the question could be placed on notice or answered by means of a ministerial statement (Coghill 2002). 
Initiatives aimed at improving Question Time by making it longer, by increasing the number of questions asked daily, or by enhancing the quality of replies, collectively or individually, promise useful reform - but only if the executive has the will to embrace them. Clearly, however, while finer points such as the duration of Question Time and the length of questions are important, the first challenge is to increase the number of genuine questions (and answers) in both houses and, by doing so, to improve their efficacy as legislative scrutiny tools. This could be achieved through more definitive presiding officer rulings over the nature and content of questions - such rulings to derive their very real authority from the standing orders.

The best way forward almost certainly lies in implementing the remainder of the 1982 Hayden reform proposals and in ensuring that they are observed. Among the most effective means of achieving this would be to reshape the offices of President and Speaker so as to give them greater powers over the conduct of Question Time (as in Britain, in the case of the Speaker). Some of Hayden's recommendations have been in place in the British House of Commons for many years. These include the assignment of certain days on which MPs can question the staff of specific departments of state about their activities; provision for 'Cross-Cutting Questions' (a practice inaugurated in January 2003) whereby a number of ministers attend to answer questions on a topic encompassing the responsibilities of several government departments (a reform prompted by the 'cross-cutting' focus of 'joined-up government', which has strong resonances in Australia as 'whole of government'); and a separate Prime Minister's Question Time, whose existence eases pressure on the main Question Time.

The role of the presiding officers (notably, the independent Speaker of the House of Commons in the British context), in the Australian Parliament, if such reform were to be seriously contemplated here, cannot be overstated. In Britain, '[t]he Speaker controls the pace of Question Time', and he (or she) has the power 'to check a Member or Minister who is either too lengthy or is using Question Time as an opportunity for debate' (HCIO 2005, p. 5). The outcome is a Question Time that, through its provision for 'oral questions', serves well the interests of parliamentary scrutiny of government and public administration. Another significant factor in the effective functioning of the British Question Time machinery is the regular scrutiny of the parliamentary questions apparatus by Parliament itself. Since the Second World War - in contrast to Australian practice (though this is changing) — the subject has been investigated by British parliamentary select committees on 13 occasions (in 1946, 1958, 1965, 1970, 1972, 1976, 1990, 1993, 1994, 1995, 1997, 2002 and 2005). Since the election of the hung Parliament, the then speaker Harry Jenkins initiated some informal changes to increase the institution's independence, such as promising not to interact with his ALP colleagues 
New Accountabilities, New Challenges

until after the house had risen on Thursday evenings. However, these changes were self-imposed and, as a result of their uncodified nature, were able to be abandoned by any future speaker.

Table 1: Questions without Notice 1964-2011 (number asked annually)

\begin{tabular}{|c|c|c|}
\hline & Senate & House of Representatives \\
\hline 1964 & 999 & 1,557 \\
\hline 1965 & 803 & 1,796 \\
\hline 1966 & 687 & 1,056 \\
\hline 1967 & 1,063 & 1,164 \\
\hline 1968 & 1,408 & 1,298 \\
\hline 1969 & 158 & 905 \\
\hline 1970 & 1,903 & 1,187 \\
\hline 1971 & 2,439 & 1,218 \\
\hline 1972 & 1,886 & 1,024 \\
\hline 1973 & 2,625 & 1,219 \\
\hline 1974 & 1,750 & 782 \\
\hline 1975 & 1,884 & 956 \\
\hline 1976 & 2,429 & 1,447 \\
\hline 1977 & 1,954 & 1,021 \\
\hline 1978 & 1,983 & 1,098 \\
\hline 1979 & 2,008 & 1,033 \\
\hline 1980 & 1,487 & 762 \\
\hline 1981 & 1,758 & 943 \\
\hline 1982 & 1,663 & 709 \\
\hline 1983 & 1,263 & 597 \\
\hline 1984 & 1,238 & 591 \\
\hline 1985 & 1,424 & 734 \\
\hline 1986 & 1,669 & 934 \\
\hline 1987 & 1,507 & 900 \\
\hline 1988 & 1,384 & 715 \\
\hline 1989 & 1,903 & 665 \\
\hline 1990 & 1,305 & 453 \\
\hline 1991 & 1,893 & 861 \\
\hline 1992 & 1,713 & 616 \\
\hline 1993 & 1,181 & 429 \\
\hline 1994 & 1,702 & 890 \\
\hline 1995 & 1,464 & 863 \\
\hline 1996 & 1,469 & 1,127 \\
\hline 1997 & 1,757 & 1,482 \\
\hline 1998 & 1,176 & 998 \\
\hline
\end{tabular}


3. Parliamentary Scrutiny of the Australian Public Service

\begin{tabular}{|r|r|r|}
\hline & \multicolumn{1}{|c|}{ Senate } & \multicolumn{1}{|c|}{ House of Representatives } \\
\hline 1999 & 1,671 & 1,370 \\
\hline 2000 & 1,572 & 1,353 \\
\hline 2001 & 1,050 & 927 \\
\hline 2002 & 1,236 & 1,220 \\
\hline 2003 & 1,333 & 1,194 \\
\hline 2004 & 1,030 & 1,008 \\
\hline 2005 & 1,069 & 1,274 \\
\hline 2006 & 1,111 & 1,293 \\
\hline 2007 & 737 & 904 \\
\hline 2008 & 1,050 & 1,290 \\
\hline 2009 & 1,368 & 1,187 \\
\hline 2010 & 1,052 & 948 \\
\hline 2011 & 1,453 & 882 \\
\hline
\end{tabular}

Source: Commonwealth Parliamentary Debates.

\section{Questions on Notice}

Parliamentarians' areas of interest in APS administration from 1964 to 2011 as reflected in Questions on Notice were similar to those for Questions without Notice. In the 1960s, rarely did a Minister decline to provide an answer to a Question on Notice on the ground that the time and work involved in preparing a response would unwarrantably burden departmental staff. However, such a reply became more and more common during the 1970s and 1980s. Prime Minister William McMahon reminded MPs in August 1971 that 'the resources of Ministers and departments are not unlimited and, notwithstanding the importance of providing the Parliament with the information it seeks, there are competing demands' (CPD, House of Representatives, 26 August 1971, p. 798).

The leader of the government in the Senate, Sir John Carrick, was similarly direct in October 1982: 'I am not prepared to authorise the large diversion of resources in Departments which would be needed to answer [the Senator's] question in the terms asked.'

Nevertheless, as was common practice in such instances, he offered a compromise in the interests of scrutiny: 'If the honourable senator would like to rephrase his question so as to refer to a shorter period of time and to focus more precisely on his area of interest, Ministers will consider what assistance can be given' (CPD, Senate, 27 October 1982, p. 1927). 
With the expansion of the APS and the wider public sector throughout the 1990s and early 2000s, Questions on Notice underwent a number of changes. Increasingly, many such questions took on an 'analytical' rather than a merely 'informational' character. The following inquiry (from 1991) is a good example:

\section{Australian Public Service}

(Question No. 740)

Are members of the Australian Public Service (APS) who are seconded to the staff of Ministers and Members of Parliament not denied the right to pursue their careers when they return to the APS?

Does existing legislation protect the rights of public servants who have worked on the personal staff of Members from all parties and whose characters have been impugned? (CPD, House of Representatives, 13 May 1991, p. 3616).

Putting aside the fact that departmental-ministerial/parliamentary staff interchange was largely an uncontroversial issue in earlier times (as distinct from the role of ministerial advisers) it is unlikely that such a question would previously have been coined in such subjective terms. Formerly, even questions seeking information to be used for a 'political' purpose, were couched more in terms of an information-seeking request.

Many have also become complex, focusing on the minutiae of governance in a few key areas such as staff numbers, program implementation and audit, the composition and make-up of ministerial adviser teams, outsourcing, and performance management (of both APS employees and organisations). Whereas previously, ministers and/or leaders of the government in each house had almost invariably refused to provide replies that would unjustifiably strain departmental resources, they were now promising to do so in respect of the most detailed questions, whether informational or analytical (see, for example, 'Australian Taxation Office: Staff' (No. 991), CPD, 17 February 2000, pp. 1386013864). By 2005, the provision of replies on this scale had become a growing burden on employees, one which was hampering their capacity as policymakers and service providers to the extent that it was identified publicly as a serious issue by the then secretary of the Department of the Prime Minister and Cabinet, Dr Peter Shergold (2005).

Paradoxically, while the average number of questions placed on notice between 2000 and 2004 in each house did not rise significantly compared with that for the years 1970 to 2000, the delays in providing answers to questions (4, 6, 12 and even 18 months) is further evidence of this problem (CPD, House of Representatives, 13 March 2000, pp. 14, 437; 6 September 2000, pp. 20, 
272-274). Such delays or 'slippage' had occurred occasionally in the past, with one MP recommending the adoption of the then House of Commons procedure requiring that all Questions on Notice ('written questions') be answered within one week of their being put on the Notice Paper (CPD, House of Representatives, 16 March 1971, p. 890). However, the situation did not improve, prompting Dr Shergold (as we have seen) to call for some relief for the beleaguered APS in August 2005.

Table 2: Questions on Notice 1964-2011

\begin{tabular}{|l|r|r|r|r|}
\hline & \multicolumn{1}{|c|}{ Senate } & & \multicolumn{2}{c|}{ House of Representatives } \\
\hline & Total questions & Annual average & Total questions & Annual average \\
\hline $1964-69$ & - & - & 4,907 & 818 \\
\hline $1970-79$ & 9,002 & 900 & 22,025 & 2,202 \\
\hline $1980-89$ & 8,780 & 878 & 16,992 & 1,699 \\
\hline $1990-99$ & 8,266 & 826 & 9,271 & 927 \\
\hline $2000-11$ & 13,197 & 1,199 & 6,017 & 1,203 \\
\hline Total/average & $\mathbf{3 9 , 2 4 5}$ & 957 & $\mathbf{6 7 , 3 5 0}$ & $\mathbf{1 , 4 3 2}$ \\
\hline
\end{tabular}

Source: Commonwealth Parliamentary Debates.

Following their peak in 2005, Questions on Notice were sustained at high levels in both the House of Representatives and the Senate until the demise of the Howard government in 2007. And, while the number of Questions on Notice in the Senate has remained fairly stable since the change of government, in the House of Representatives the number of Questions on Notice has collapsed dramatically. In the House of Representatives, the average time in which to obtain an answer to a Question on Notice in 2007-08 was 207 days before the change of government; after this it was only 26 days. The results were similar in the Senate: previously it had taken 115 days to provide an answer to Questions on Notice, and this improved to 55 days after the change in government (CPD, Senate, 13 November 2008, p. 26). There is little doubt that the Question on Notice, as it is presently perceived and framed, will remain a valuable tool of legislative scrutiny. Yet, it is clear that some refinement of the scope and degree of detail of many questions is urgently needed (the number does not present a problem - it is excessive in neither house). This could be arrived at through executive-opposition front bench agreement on the need for such reform and/or (as with Questions without Notice) the provision of greater powers to the presiding officers to assess the content and purpose of questions and to ensure that they are answered by a certain date (the British no longer have a parliamentary rule requiring this: HCIO 2005, p. 11). Only then, perhaps, will this growing problem be satisfactorily addressed. 
New Accountabilities, New Challenges

Table 3: Questions on Notice 1964-2011 (number asked daily)

\begin{tabular}{|c|c|c|}
\hline & Senate & House of Representatives \\
\hline 1964 & - & 814 \\
\hline 1965 & - & 714 \\
\hline 1966 & - & 654 \\
\hline 1967 & - & 752 \\
\hline 1968 & - & 1,072 \\
\hline 1969 & - & 901 \\
\hline 1970 & 817 & 2,269 \\
\hline 1971 & 969 & 2,682 \\
\hline 1972 & 757 & 1,626 \\
\hline 1973 & 607 & 1,683 \\
\hline 1974 & 560 & 2,875 \\
\hline 1975 & 677 & 1,534 \\
\hline 1976 & 1,658 & 1,870 \\
\hline 1977 & 642 & 2,221 \\
\hline 1978 & 1,116 & 3,126 \\
\hline 1979 & 1,199 & 2,139 \\
\hline 1980 & 1,137 & 1,694 \\
\hline 1981 & 1,443 & 3,347 \\
\hline 1982 & 1,700 & 2,214 \\
\hline 1983 & 647 & 1,002 \\
\hline 1984 & 587 & 910 \\
\hline 1985 & 762 & 3,115 \\
\hline 1986 & 818 & 1,876 \\
\hline 1987 & 399 & 1,180 \\
\hline 1988 & 589 & 876 \\
\hline 1989 & 698 & 778 \\
\hline 1990 & 423 & 507 \\
\hline 1991 & 1,221 & 753 \\
\hline 1992 & 896 & 927 \\
\hline 1993 & 957 & 826 \\
\hline 1994 & 970 & 1,044 \\
\hline 1995 & 783 & 961 \\
\hline 1996 & 373 & 1,159 \\
\hline 1997 & 641 & 1,446 \\
\hline 1998 & 568 & 861 \\
\hline 1999 & 1,434 & 787 \\
\hline 2000 & 1,392 & 1,132 \\
\hline 2001 & 675 & 713 \\
\hline 2002 & 1,054 & 1,281 \\
\hline
\end{tabular}


3. Parliamentary Scrutiny of the Australian Public Service

\begin{tabular}{|c|c|c|}
\hline & Senate & House of Representatives \\
\hline 2003 & 1,439 & 1,604 \\
\hline 2004 & 1,000 & 1,287 \\
\hline 2005 & 1,149 & 2,522 \\
\hline 2006 & 1,497 & 2,358 \\
\hline 2007 & 527 & 1,046 \\
\hline 2008 & 1,210 & 554 \\
\hline 2009 & 1,304 & 616 \\
\hline 2010 & 837 & 421 \\
\hline 2011 & 1,113 & 621 \\
\hline
\end{tabular}

Source: Commonwealth Parliamentary Debates.

\section{The Matter of Public Importance}

The Matter of Public Importance (MPI) continues to be underrated as a tool of scrutiny by students of politics and public administration alike. As one academic commentator expresses the traditional view of MPIs: 'An MPI debate is really only an invitation to comment on a "matter for discussion", with no vote taken, as would be the case in a censure motion.' He concludes that, 'The parliamentary discussion is simply timed out. But it is a useful opposition tactic for getting arguments and evidence on the public record' (Uhr 2005, p. 11).

However, an analysis of the parliamentary record between 1964 and 2011 indicates the picture to be less clear-cut. The MPI, under this or earlier names, ${ }^{2}$ has been employed to highlight significant gaps in public policy or issues in need of sustained attention. Prominent, early examples of this include those dealing with 'Equal Pay for Equal Work' (CPD, House of Representatives, 1 May 1962, pp. 1741-1753), 'Public Service', (CPD, House of Representatives, 14 May 1963, pp. 1288-1300); 'Commonwealth Public Service Annual Leave and Employment Conditions' (CPD, House of Representatives, 4 March 1970, pp. 54-60, 13 May 1970, pp. 2049-2063); 'Government Contracts' (CPD, House of Representatives, 8 March 1973, pp. 362-376); and, in the Senate (where it is employed far less than in the lower house), 'Review of Commonwealth Functions' (the alleged inadequacy and deleterious community effects of this review) (CPD, Senate, 11 November 1981, pp. 2018-2021). In contrast to earlier decades, several MPIs (in 1993 and 2003-04 in particular, relating to one minister's financial

2 Throughout this period, the term MPI was generally employed in the House of Representatives. In the Senate, the term Matter of Urgency (MoU) was used instead of MPI between 1963 and 1977, both MPI and MoU being employed interchangeably in 1978 and 1979. Since 1980, an MPI has been identified in the Senate independently of an MoU and a Matter of Public Interest (MoPI). 
practices and the issue of APS politicisation, respectively) have raised awareness (among Senators and MPs, at least) of the MPI as a scrutiny vehicle (they will be examined in greater detail later).

Since 1990, the MPI has become a more common feature of parliamentary business in both houses. As well as the predictable interest in policy matters (mainly economic and foreign), ministerial decisions and public sector performance, there is a strong concern with the health of the institutions of governance and public administration. Major examples include 'Government Financial Management' (especially 'the process of government': CPD, Senate, 24 August 1990, pp. 2184-2204); 'Department of Social Security: Administration' ('The continuing failure of the Minister for Social Security to address the multitude of administrative problems currently besetting his Department': CPD, Senate, 11 October 1990, pp. 2921-2945); 'APS Politicisation' ('The growing politicisation of the public service, and attempts by the Government to withhold important information from parliament through doctoring and withholding reports': CPD, Senate, 12 August 2003, pp. 13343-13357); and 'APS Politicisation' ('That the Senate expresses its deep concern at the continuing politicisation of the public sector by the Howard Government': CPD, Senate, 25 March 2004, pp. 21986-22006). The MPI is now an established tool for such scrutiny in Senate deliberations.

Among notable House of Representatives examples are those dealing with damage to public confidence in the government's stewardship of public administration: 'The Operation of the Australian Loan Council' (CPD, House of Representatives, 3 November 1992, p. 2394; 4 November 1992, p. 2574; 5 November 1992, pp. 2748-2758); 'Australian Quarantine and Inspection Service' ('The government's failure to reform both the efficiency and culture of the Australian Quarantine and Inspection Service which is hampering Australia's competitiveness in world markets': CPD, House of Representatives, 16 December 1993, p. 4240); 'Commonwealth Financial Management' ('The government's failure to prudently manage the Commonwealth's finances': CPD, House of Representatives, 8 November 2000, pp. 22442-22453)'; and, 'Howard Government: Denigration of Government Institutions' ('The persistent failure of the Government to be accountable and to tell the truth, denigrating in the process institutions fundamental to Australian democracy, including the public service, the defence forces, the Parliament and the courts': CPD, House of Representatives, 21 March 2002, pp. 1921-1922).

3 One of the issues emphasised here was the 'radical decentralisation' of responsibility under the provisions of the Financial Management and Accountability Act 1997, which had - it was argued - contributed to a significant decline in Department of Finance and Administration supervision of departments engaging in foreign exchange related transactions. 
The insistence of Senators and MPs that the MPI process be properly observed and the procedure's forensic nature, breadth, depth and coverage (especially since 1990) attest to the status they accord it (and to its effectiveness) as a vehicle of scrutiny. The opposition leader, E. G. Whitlam, in March 1970 was at pains to stress that, so far that year, the opposition had raised five MPIs, and each time the debate was gagged after one speaker from each side had spoken. He pointed out that in 1969 the average number of speakers had been four and, between 1960 and 1970, no fewer than three speakers on each side spoke on MPIs (CPD, House of Representatives, 18 March 1970, p. 561). Thirty years later, Dr Andrew Theophanous referred to this continuing problem as constituting, if not an abuse of procedure, then certainly a regrettable practice, when he argued that time be allocated to enable independent MPs to speak on MPIs and the Business of the House not be brought on precipitately, thus precluding them from speaking (CPD, House of Representatives, 6 September 2000, p. 20272). No doubt this premature curtailing of the MPI process in order to stifle or smother debate (amounting to attempted strangulation at birth in the cases of the Australian Loan Council and the Australian Quarantine and Inspection Service) and marked 'Denigration of Government Inspections' in other cases restricts scrutiny.

As a result of the reforms to parliamentary standing orders in September 2010, three substantive changes were made to MPIs. First, they increased the amount of time allowed for discussion to one hour and 30 minutes. This would permit the proposer and the next speaker to speak for 15 minutes and any following speakers for 10 minutes (CPD, House of Representatives, 29 September 2011, p. 117). Second, MPIs are now discussed directly after Question Time, thereby raising their prominence. Third, the agreement also outlined the principle that there should be a proportionate share of time for MPIs in order that all non-government members would have adequate time allotted (House of Representatives 2010, p. 4). However, additional changes would further improve the situation. For example, standing orders could be altered to make it mandatory for a minimum of four Senators and MPs to speak for a specified minimum length of time on each MPI. Notwithstanding this problem, the MPI remains a more estimable tool for scrutiny by the non-government parties (its main purpose anyway) than is often supposed. Few better examples of this can be found than the 'Community Grants' or so-called 'Sports Rorts Affair' of late 1993, which was pursued vigorously via the MPI process (the result being a ministerial resignation and the implementation of improved accountability processes earlier recommended by the Auditor-General). Two influential MPIs were involved here: 'Community Grants' ('The failure of administration in the Department of the Arts, Sport, the Environment and Territories as exemplified by the blatant misuse of taxpayers' money for political purposes': CPD, House of Representatives, 17 November 1993, pp. 3018-3027), and 'Community 
Grants' ('The failure of the Minister for the Environment, Sport and Territories to adequately respond to the efficiency audit of the Auditor-General on the community cultural, recreational and sporting facilities program': CPD, House of Representatives, 22 November 1993, p. 3288).

The number of MPIs being raised in each house is another issue requiring attention. Since 1964, in every year except four $(1983,1984,1989,2011)$ the number of MPIs raised in the House of Representatives has been almost, and often more than, double that in the Senate (a total of 1,841 in the lower house as against 626 in the Senate). Clearly, further procedural reform (again, by means of standing orders) is needed to resuscitate the MPI as a vehicle for scrutiny in the upper house. The figures underline the need starkly: Senate MPIs 1997-2011, 152; House of Representatives MPIs 1997-2011, 664. The MPI has certainly proved itself a useful tool of scrutiny, and it is true that, as one former Senate Deputy President and MP put it, the MPI process offers the opposition and smaller parties 'very fair opportunities to put their point of view' (Hamer 2004, p. 294). Nevertheless, the MPI (particularly in the Senate) could clearly be rendered a sharper tool by addressing the issues of MPI debate gagging and the small numbers of Senate MPIs.

Table 4: Matters of Public Importance 1964-2011 (number raised annually)

\begin{tabular}{|c|c|c|}
\hline & Senate & House of Representatives \\
\hline 1964 & 4 & 11 \\
\hline 1965 & 3 & 6 \\
\hline 1966 & 3 & 5 \\
\hline 1967 & 9 & 12 \\
\hline 1968 & 1 & 10 \\
\hline 1969 & 6 & 28 \\
\hline 1970 & 10 & 22 \\
\hline 1971 & 12 & 23 \\
\hline 1972 & 5 & 21 \\
\hline 1973 & 6 & 18 \\
\hline 1974 & 3 & 32 \\
\hline 1975 & 3 & 26 \\
\hline 1976 & 9 & 47 \\
\hline 1977 & 16 & 48 \\
\hline 1978 & 16 & 56 \\
\hline 1979 & 25 & 52 \\
\hline 1980 & 28 & 33 \\
\hline 1981 & 31 & 51 \\
\hline 1982 & 32 & 46 \\
\hline 1983 & 23 & 42 \\
\hline
\end{tabular}


3. Parliamentary Scrutiny of the Australian Public Service

\begin{tabular}{|c|c|c|}
\hline & Senate & House of Representatives \\
\hline 1984 & 23 & 41 \\
\hline 1985 & 26 & 57 \\
\hline 1986 & 14 & 71 \\
\hline 1987 & 14 & 65 \\
\hline 1988 & 22 & 47 \\
\hline 1989 & 31 & 44 \\
\hline 1990 & 14 & 31 \\
\hline 1991 & 14 & 46 \\
\hline 1992 & 13 & 45 \\
\hline 1993 & 3 & 17 \\
\hline 1994 & 23 & 47 \\
\hline 1995 & 20 & 40 \\
\hline 1996 & 12 & 37 \\
\hline 1997 & 3 & 52 \\
\hline 1998 & 8 & 30 \\
\hline 1999 & 9 & 45 \\
\hline 2000 & 2 & 50 \\
\hline 2001 & 4 & 35 \\
\hline 2002 & 3 & 43 \\
\hline 2003 & 8 & 45 \\
\hline 2004 & 5 & 46 \\
\hline 2005 & 14 & 51 \\
\hline 2006 & 9 & 50 \\
\hline 2007 & 5 & 39 \\
\hline 2008 & 9 & 44 \\
\hline 2009 & 20 & 45 \\
\hline 2010 & 21 & 40 \\
\hline 2011 & 32 & 49 \\
\hline
\end{tabular}

Source: Commonwealth Parliamentary Debates.

\section{Committees of the Parliament}

Committees are the best known features of the parliamentary scrutiny machinery.

The Sydney Morning Herald of 20 June 2005 contained the findings of a survey of 46 Senate inquiries undertaken since 1996, most of whose major recommendations, according to survey authors Gerard Ryle and Lisa Pryor, have been largely ignored (Ryle and Pryor 2005). At first sight, figures for inquiry duration, number of report recommendations and estimated cost of these investigations 
make the Senate committee system appear to some degree to be a luxury of governance. While a relatively easy picture to create, this is in many respects misleading. The wide-ranging nature of Senate (and House of Representatives) committee inquiries, even if the majority of their findings are not implemented, still makes committees an influential tool of scrutiny. Although many committee recommendations are integrated into legislation and APS practice, it should be recognised that few governments have the capacity to reshape what are frequently complex spheres of governance by enshrining into public policy the numerous recommendations made by committees (some reports contain almost 100 recommendations). Politics and public administration essentially are exercises in reconciling resources with the most suitable avenue of policy; in this instance, to criticise governments for not implementing recommendations on such a scale never (or highly unlikely ever to have been) realisable anyway, is a superficial criticism that takes little account of the political or administrative challenges of governance.

It is perhaps also necessary to arrive at a more balanced view than that usually advanced in relation to recent committee work. As one Senator put it in December 2005 on the subject of committee activity since the government began to exercise its Senate majority (from 1 July of that year): 'we have seen the number of committee references that have been agreed to halved and, correspondingly, the number of committee references opposed doubled. That shows another example of the significant amount of scrutiny that has been prevented' (CPD, 8 December 2005, pp. 133-134).

He went on to protest against the government's refusal 'to allow scrutiny of basic broad policy matters', notably, by means of frequent use of the 'gag' or 'guillotine' in order to prevent or limit debate on proposed committee references. Yet, he called for a sense of perspective in discussions of this and related matters:

I think it is important that we try to put a bit of a brake on this continual 'tit-for-tat' and dragging back through Hansards of the last 20 years, because none of us have totally clean hands here. We all know that guillotine motions can be justified. Every party in this place ... voted for guillotines at various times.

This seems a useful plea for more measured commentary on developments in both houses.

Since the reforms to parliamentary procedure in 2010, the House of Representatives committees have undergone somewhat of a revival. The changes to the committee system outlined in clause 10 of the agreement (House of Representatives 2010, p. 6) and implemented through the standing orders (20 October 2010) were: 
1. Reducing the number of committees from 12 to nine;

2. Reducing the number of committee members to seven;

3. Increasing the number of supplementary members from two to four thereby allowing greater participation of parliamentary members in committee business;

4. Stipulating that the Joint Committee of Public Accounts and Audit be chaired by non-government members;

5. Allowing the selection committee to refer controversial bills for further scrutiny by the relevant standing or joint committee;

6. Encouraging faster response times by government by requiring a ministerial explanation to the house if government responses are not received within six months; and

7. Enabling committee chairs and deputy chairs to make statements in the house about new inquiries during private members' business time.

The reduction in the number of standing committees was effectively cancelled out by the increase in the number of joint standing and select committees, having a negligible effect on the workload of Senators and MPs. As yet it is difficult to determine the effectiveness of the six-month time frame for government responses to reports. The time limit has elapsed for 14 reports, of which nine have since received a government response. As a result of the reforms, 67 out of 300 bills considered were referred by the Selection Committee for further scrutiny, comprising about one-fifth of government business. This compares favourably with the period 1994-2010 when only 16 bills underwent further investigation by house committees. In addition, the number of amendments made to bills based on committee recommendations has lead the House Standing Committee on Procedure to consider this reform a success.

\section{Australian National Audit Office (Auditor-General)}

The Audit Act 1901 regulated the Auditor-General's first period of activity (190197), during which (in accordance with the legislation) he concentrated almost entirely on financial audit processes and financial accountability in a narrowly prescribed sense. Since 1998, under the terms of the Auditor-General Act 1997, audit goals and a greater emphasis on enhancing public sector efficiency have been the chief focus of the ANAO. An independent auditor, responsible for scrutiny of the Auditor-General's office itself, was appointed in May 1979. During the years under review here (1964-2011), with the exception of the first 'efficiency audit', this situation endured until 1983-84 when efficiency audits of APS operations and performance became an established part of ANAO 
activity (they remained so, along with the project audit — instituted in 1991 - until 1995). Since then the dominant form of audit has been the performance audit (formerly known as an audit report). Since 1998, the ANAO has devised a number of other types of audit: the assurance and control assessment audit; the business support process audit; the compliance assessment audit; the financial control and administration audit; and, the financial statement(s) audit. The ANAO's internet pages, which are among the most accessible and detailed of any Australian government (or associated) body, and the Indexes to Papers Presented to Parliament, contain an informative (and definitive) listing of all of its reports.

Its numerous important publications (many of which produce findings with implications for the whole field of public administration rather than for just the issue or agency under investigation) include 'Survey of Internal Audit in the Commonwealth Public Sector' (ANAO 1990); 'Accountability off the Rails National Rail Corporation Limited: Erosion of Accountability to the Parliament' (ANAO 1991a); 'Implementation of Purchasing Reforms in the Australian Public Service' (ANAO 1991b); 'Financial Management: Department of Veterans' Affairs' (ANAO 1995); 'The Administration of the Australian National Training Authority' (ANAO 1996); 'Survey of Fraud Control Arrangements in APS Agencies' (ANAO 2000); 'Recordkeeping' (ANAO 2002); 'Absence Management in the Australian Public Service' (ANAO 2003a); 'Administration of Staff Employed under the Members of Parliament (Staff) Act 1984: Department of Finance and Administration' (ANAO 2003b); 'Annual Performance Reporting' (ANAO 2003c); and 'Performance Management in the Australian Public Service' (ANAO 2004b).

The 1997 legislation and consequential amendments to the Public Accounts Committee Act 1951, which also involved a change of name for the committee to Joint Committee of Public Accounts and Audit (JCPAA), marked a transfer from the executive to the Parliament of independent audit scrutiny (by the JCPAA) of government and the APS. The act also ensured that, henceforth, the AuditorGeneral would be more independent of both the executive and the Parliament by virtue of the considerable powers given to the JCPAA. Two parliamentary officers summed up the new arrangements in May 2001 as follows:

The Auditor-General, by conducting financial and performance audits of Commonwealth agencies provides the technical expertise and detailed scrutiny necessary for the effective evaluation of public service performance. Parliament depends on the Auditor-General's reports as a basis for further public inquiries.

By strengthening the independence of the Auditor-General and his office from the Executive and enhancing the role of Parliament in relation to the Auditor-General as both guardian and client, Parliament has gained 
some crucial extra weighting in the ever changing dynamic of checks and balances that pervade Australian democracy (Kerley and Harris 2001, pp. 11-12).

The year 1997 ushered in 'a new legislative era' for the Auditor-General's activities, which saw routine financial auditing eclipsed (or at least matched) by auditing intended to 'add value and improve public administration' (Wanna, Ryan and Ng 2001, pp. 288, 295). The Royal Commission on Australian Government Administration's 1976 call for 'a renewed vitality' for the audit function (in the form of a wider and sharper reporting brief and a parliamentary committee with greater powers) had clearly been answered (RCAGA 1976, p. 375). Yet the ANAO further sought to improve APS accountability, not only through 'an integrated audit approach' (Barrett 2004, p. 8), but also by advancing public sector practice via initiatives such as 'Better Practice Guides'. These are designed to translate ideas and procedures of proven success in some organisations to other parts of the public sector. Thirty-three such guides were produced between June 1996 and December 2011 covering areas like 'Audit Committees' (July 1997) and 'Managing Parliamentary Workflow' (April 2003). They play 'a desirable and valuable role in supporting improved public administration' (Coghill 2004, p. 6).

A retired Auditor-General has referred to a number of challenges facing the ANAO. Towards the end of his tenure, the question of lower funding resulting from projected budget cuts and the potential threat this constituted to the ANAO's capacity to discharge its duties prompted him to express his concerns in a letter to the Prime Minister in early 2005 (Lewis 2005, pp. 1-2). This could be addressed by achieving a better balance between what appears to be a possible overemphasis on detailed reporting, and examinations of general trends, namely, less micro and more macro evaluation (the APS Senior Executive Service, for example, has been the subject of several micro but few - and then not at all recent - macro reviews). Another issue he identified related to how the organisation could 'strike the right balance of audit activity across the public service to fulfil [its] statutory obligations, while meeting the particular demands of Parliament and individual agencies. The key to this outcome is understanding the Parliament's priorities and the business/functional imperatives of agencies that are creating a need for audit examination' (Barrett 2004, pp. 2-3, 8).

The authors of the ANAO history may have had something like this in mind when they wrote, three years earlier, that 'the tyranny of Parliament over the auditor-general could be equally as threatening to the independence of the office as the tyranny of the executive' (Wanna, Ryan and Ng 2001, p. 289). Fortunately, there are no signs of this happening and the 1997 reforms must be judged a success. The Auditor-General's role in Australian governance continues to be 
New Accountabilities, New Challenges

'a moderating one', with the ANAO acting as 'a unifying influence, improving interconnectedness by strengthening the influence of values of openness and transparency' (Coghill 2004, p. 7).

The ANAO could partly address its limited funding by redirecting existing funding to more broad-ranging audits and through a reduced emphasis on what might be termed micro auditing. This would entail a smaller focus on the minutiae of administration in the case of the APS. A combination of these approaches may well provide a workable and successful future model for the ANAO. It could, for example, undertake fewer micro audits (ANAO 2005b) and more macro audits (ANAO 2005a). The former could profitably be less detailed and time- and resource-consuming, and the latter focused more on the enunciation for the whole APS of general principles and guidance tools absorbed from ANAO experience.

Table 5: 'Audit' reports of the Auditor-General 1989-90 to 2010-11 (number tabled/presented)

\begin{tabular}{|c|c|}
\hline $1989-90$ & 29 \\
\hline $1990-91$ & 34 \\
\hline $1991-92$ & 53 \\
\hline 1992-93 & 38 \\
\hline 1993-94 & 44 \\
\hline 1994-95 & 31 \\
\hline 1995-96 & 33 \\
\hline 1996-97 & 40 \\
\hline 1997-98 & 50 \\
\hline 1998-99 & 49 \\
\hline $1999-2000$ & 52 \\
\hline 2000-01 & 54 \\
\hline $2001-02$ & 67 \\
\hline $2002-03$ & 63 \\
\hline $2003-04$ & 59 \\
\hline $2004-05$ & 59 \\
\hline $2005-06$ & 51 \\
\hline $2006-07$ & 53 \\
\hline $2007-08$ & 46 \\
\hline $2008-09$ & 48 \\
\hline $2009-10$ & 50 \\
\hline $2010-11$ & 57 \\
\hline
\end{tabular}

Source: Australian National Audit Office. 


\section{Budget evaluation and appropriation processes}

The Commonwealth financial scrutiny framework, specifically the budget and appropriation machinery, was transformed between 1964 and the early 2000s. Although public accountability now emanates (as it did a generation ago) from a single 'source of initiative' — the Parliament (Reid 1981, p. 133) - the financial scrutiny apparatus has become more complex and been reshaped by greater community pressure for better services, as well as the accountability requirements generated by expanded and more intricate government outsourcing and procurement arrangements. Both the formal political expression of this change (for example, administrative law) and its informal manifestations (for instance, adroit and systematic use of the media by individuals, organisations and interest groups) have produced greater accountability demands on ministers and the APS, and increased the need for improved financial structures and practices to underpin their activities (O'Faircheallaigh, Wanna and Weller 1999, pp. 296-297).

Given its importance to sound governance, the issue of the effectiveness of the financial accountability structures and processes remains a central one. L. J. Hume, writing in June 1963, warned of the danger that' in the Commonwealth Parliament the work of scrutiny will become wholly ineffective, and that the annual financial routine will degenerate into a ritual' (Hume 1963, p. 165).

The financial documents debated by Parliament, he stressed, focused too much on 'certain technical details of the government's book-keeping' instead of on 'the broad economic impact and implications of programmes' (Hume 1963, pp. $165,166)$. Despite such well-argued calls (which were prescient about what would come to pass 20 years on), reform in this area was minor during the 1960 s and 1970s - with the notable exception of the appointment of Senate Estimates Committees (1970), which were given the power to examine government expenditure via systematic questioning of departmental staff.

After conducting a wide-ranging analysis of how things stood in the early and mid-1960s, one student of the subject concluded:

Efficiency of the Commonwealth public service occupies only a minor place in the considerations of the Commonwealth Parliament. Parliament's interest in public service efficiency is determined partly by concern with its own prestige; partly by political considerations derived from party or public or electoral attitudes. Only in the former does Parliament tend to act as a unit with party differences submerged; here there is evidence of a 'parliamentary' attitude. In the latter the main concern is with political issues, with questions on administration subordinate (Holzheimer 1973, p. 249). 
By 1976, the Royal Commission on Australian Government Administration had become convinced that the establishment of a forward estimates process was essential to sound Commonwealth financial management. Such reform would be 'central to the task of rational coordination of policies as well as the efficient use of resources' (RCAGA 1976, p. 357). The 1980s were to witness far-reaching changes which reshaped parliamentary financial scrutiny of APS operations; indeed, they altered the whole landscape of government financial management. The main initiatives were:

- Review of Commonwealth Administration: J. Reid, January 1983 - emphasis on the importance of APS and governmental financial accountability and management;

- Financial Management Improvement Program - Diagnostic Study: Public Service Board and Department of Finance, February 1984 - promotes the practice of 'program budgeting' which is introduced later that decade;

- Budget Reform - A Statement of the Government's Achievements and Intentions in Reforming Australian Government Financial Administration: Department of Finance, April 1984 - recommends that better methods of identifying and establishing budget priorities be devised; and

- Efficiency Audit created to enhance APS financial functions: September 1986 (Verspaandonk and Holland 2003).

The 1990s saw an even more significant series of reforms:

- Financial Management and Accountability Act 1997 (FMA Act) - introduced responsibilities for agency heads in areas such as fraud (s. 45), the establishment of an audit committee (s. 46), debt recovery (s. 47), recordkeeping (s. 48) and providing the Auditor-General with financial statements in the required form (s. 49); and

- Commonwealth Authorities and Companies Act 1997 (CAC Act) — introduced a single set of core reporting and auditing requirements for the directors of Commonwealth authorities and companies that are separate legal entities established for a public purpose (and which are entitled to hold money in their own right).

The remaining key budget and appropriation accountability mechanisms under the FMA Act are FMA regulations, FMA delegations, chief executive's instructions, FMA orders, financial statement orders, and the 'Commonwealth Procurement Guidelines' (of which more later).

The need to ensure greater scrutiny of government contracting resulted in the Senate Order of 20 June 2001, which required ministers to table, twice yearly, letters of advice that agencies they administered under the FMA Act had placed on the internet lists of current contracts (to the value of $\$ 100,000$ or more) into 
which these agencies had entered. The Auditor-General provides regular reports on this process (twice annually until December 2003 and once a year since then: ANAO 2004c, p. 21; Holland 2003). Documentation relating to maintaining the confidentiality of commercial information in connection with contracting and procurement activities is contained in the Department of Finance and Administration's publications, the 'Commonwealth Procurement Guidelines' (Finance and Administration 2004) and 'Confidentiality of Contractors' Commercial Information' (Finance and Administration 2003).

The wider budget framework comprises a number of elements. They are annual appropriations, special appropriations, special accounts, the Australian government budget, a charter of budget honesty (introduced in 1998), the preelection economic and fiscal outlook, an annual final budget outcome report, and monthly consolidated financial statements for the Government (APSC 2005a, pp. 61-73).

Australia's federal budget and appropriation arrangements are generally performing well. The reforms introduced in the 1980s and 1990s, which sought to reduce the emphasis on compliance and increase that on performance, have been successful. These include:

- The publication of the forward estimates in the interests of greater transparency;

- The introduction of program budgeting, which requires the outlining of program budgets and targets, and also that all appropriations related to that objective be certified;

- The establishment of aggregate controls, such as efficiency dividends, and identification and reporting against efficiency and effectiveness indicators; and

- The implementation (for the first time in the 1999-2000 budget) of an integrated framework of accrual budgeting, accounting and reporting, one that specifies outcomes and outputs.

Accrual accounting, which requires items to be brought to account and included in the financial statements as they are earned or incurred, rather than as they are received or paid, made it necessary for agencies to redevelop what had formerly been cash-based financial management and reporting systems (APSC 2003, pp. 93-95, 98-99).

What, then, can be said in conclusion about the present system, and how it might be refined or improved? There has been a marked change for the better in procurement and contract management activity following the introduction of the 'Commonwealth Procurement Guidelines', the Department of Finance and Administration's financial guidance document on contractors' commercial 
information, and the Senate Contracts Order, and a significant decline in the incidence of confidentiality provisions in contracts. Nevertheless, the ALP insisted in 2004 on the need for independent, credible and public benchmarks against which outsourcing and contracting proposals could more profitably be assessed (Latham and Emerson 2004, p. 4). While the ANAO found in 2004, after an audit of five medium-sized FMA Act agencies (including the Department of the Treasury), that 'generally, agencies had developed adequate control structures for the application of financial delegations for the expenditure of public monies', it was clear that 'such delegations were not always being managed in accordance with relevant legislation' (ANAO 2004a).

Interestingly, in an echo of L. J. Hume's 1963 concern with the format and contents of the financial documentation, one of the pillars of the new financial framework has been the subject of considerable debate - the Portfolio Budget Statements (PBS) themselves. In its third report on the structure and contents of the PBS (in 2000), the Senate Finance and Public Administration Legislation Committee concluded that, in view of the divergence of opinion about the proper purpose of the estimates process, 'the PBS are inevitably compromise documents'. Their make-up was not always proving helpful in 'the formulating of questions on input and process' and they were certainly not for the 'uninitiated'. But the committee could find nothing wrong in principle with the PBS layout, advising (especially senior) APS staff to familiarise themselves more with PBS introductory material and the whole subject of public sector budgeting in an attempt to enhance their understanding of the PBS process. The committee also recommended that Senate legislation committees report on the adequacy of the PBS provided to them for each set of hearings (SFPALC 2000, pp. 3-4, 39, 42).

One Senator, however (speaking in the same year), was less indulgent towards the PBS. He described it (and the Portfolio Additional Estimates Statement) as being replete with jargon, often difficult to read (indeed, sometimes unreadable), hard to follow from one year to the next because of radical format changes, and much in need of an 'English translation' or the assistance offered by a 'Guide to the Galaxy', as it appeared to him that the document could not have been put together by someone on this planet (Hogg 2001, p. 169).

Another major criticism of today's financial accountability arrangements was voiced in November 2004 by D. W. Challen:

Since the introduction of accrual budgeting in 1999, the Commonwealth government has presented two sets of budget to Parliament, and they report substantially different figures for almost every item. As a consequence, Parliament is hopelessly confused. One set of budget is based on Australian Accounting Standards formulated for [private 
sector] business applications while the other is prepared according to the Government Capital Finance Statistics standards of [the] IMF [International Monetary Fund] (Challen 2004).

Challen went on to argue that weaknesses exist in the present public sector reporting framework, particularly in relation to meeting the information needs of users; urged that the objectives and associated qualitative characteristics of public sector financial reporting should be more carefully articulated; referred to the problems which have arisen from applying the for-profit concept of financial control to the public sector; and recommended that a more appropriate definition of a government reporting entity be arrived at (Challen 2004, p. 2 and passim).

Since 1964, Australian governments of all political hues have gone to considerable trouble (especially from the early 1980s onwards) to ensure greater financial accountability for their activities. In this they have been ably assisted by the APS and the wider public sector. At present, it cannot be said that the demands of the financial framework are an impediment to sound government and efficient public administration. However, it is probably salutary to remember that 'accountability is not an unqualified good to be maximised at all costs. It must always be subject to reasonable limits in the light of other conflicting values, including practicality and cost' (Mulgan 2003, p. 236).

The institutions and requirements of financial management scrutiny as they relate to APS operations are, as argued earlier, basically sound. However, another aspect of financial accountability, which affects but is not germane to public sector activities, continues to raise concerns. It relates to 'special appropriations' (more accurately, 'standing appropriations'). These provisions permit governments to appropriate money from the Consolidated Revenue Fund; such amounts are often unspecified and for no fixed duration. In the words of one Senator: 'The significance of standing appropriations from an accountability perspective is that, once they have been enacted, the expenditure they involve does not require regular parliamentary approval and therefore escapes parliamentary control' (Murray 2005, p. 2).

The number of these (and the amounts involved) has risen markedly since federation: from 10 per cent in 1910 to 56 per cent in 1970, to over 80 per cent of all present Commonwealth government expenditure (the UK figure is 25 per cent). While the Australian Parliament undertakes no specific scrutiny of the many bills containing special appropriations, the Senate nevertheless possesses the power to remove or restrict the provisions in legislation for standing appropriations if it deems them inappropriate for the purposes of their proposed enactment (Murray 2005, p. 3). The Senate Standing Committee on the Scrutiny of Bills would be well-placed to undertake the task of examining all existing 
legislation and identifying where such provisions exist. The Senate could then determine which to retain and which to abolish (a course of action that would, of course, require the government's imprimatur). Thereafter, the Scrutiny of Bills Committee might assume this as one of its regular responsibilities.

\section{Accountability to parliamentary inquiry: Ministerial advisers and public servants}

The role of 'special' or 'ministerial' advisers in Australian governance, in particular their accountability to Parliament, emerged as a major issue during the early 1970s when the number of such appointments rose markedly in comparison with those of former decades. The implications of this trend and the main concerns to which it still gives rise were expressed by Senator John Carrick (then an opposition frontbencher) in May 1973:

People have been insinuated between the Minister and his departmental head as buffers, as indeed protectors, to prevent the department from giving its authentic and responsible view to the Minister. The special advisers are apparently immune. The advice that they give does not have to be recorded; it does not have to be documented; it is not capable in general terms of being examined by the public. I ask that in future the special advisers be present, along with the departmental officers at Estimates Committee hearings and that they be made available for examination through the Minister just as are departmental officers.

The test of the system is simple. If it is true ... that the idea of the Senate Estimates Committee is, through the Ministers, to be able to draw out of the departmental officers the facts, the thinking of the departments, to get a participatory democracy between members of the Public Service and this Parliament, then the Government of the day cannot have any alibi for preventing the special advisers being brought into the open and being subject to scrutiny (CPD, Senate, 31 May 1973, pp. 2147-2148).

None of these questions has been seriously addressed, especially concerns about the accountability of ministerial staff, by any government since then, despite a regular stream of Questions on Notice requesting details of the growing numbers, conditions of employment, salaries and other entitlements of such staff. Since the passing of the Members of Parliament (Staff) Act 1984, the total number of those employed under this legislation has risen from some 700 to 1,200, with ministerial staff numbers themselves standing in mid-2004 at approximately 400 (Latham and Faulkner 2004, p. 7). The Royal Commission on Australian Government Administration, as early as the mid-1970s, found there to be 'a lack of clarity in 
the division of responsibility between ministers and officials' (RCAGA 1976, p. 54). The debate has widened much since then with the longstanding focus on accountability recently being matched by a recognition of the need to set out clearly the respective roles of advisers and public servants. One MP identified this issue in 1981, arguing that the accountability dilemma for ministers, the APS and its staff centred on the complexity of its functions. This often resulted in ministers being placed in a position of 'ministerial answerability' rather than 'ministerial accountability'. The solution to this problem, he concluded, was a better definition of accountability requirements for department heads and senior APS employees which would assist ministers to be truly 'accountable' and not just 'answerable' (Aldred 1981, pp. 76-77). Yet, in the words of one Public Service Board chairman, as the 1980s advanced, public servants (even with their minister present) were finding themselves increasingly in the spotlight (Cole 1981 , p. 123). As early as 1982 , one commentator was speculating that public examination of APS staff at estimates and other committee hearings could allow poorly performing ministers to escape appropriate scrutiny (Uhr 1982, p. 37). A set of guidelines aimed at clarifying the position of public servants in such proceedings was tabled in Parliament in August 1984. It was later revised to take account of the Senate Parliamentary Privilege Resolutions of 25 February 1988 (Senate, Table Office 1988, p. 3; Prime Minister and Cabinet 1989).

By 1996, some observers were complaining of "the increasing "direct" accountability of public servants to Parliament' - that, more and more, senior public servants at the table, rather than ministers, were being required to answer questions and explain decisions, and to do so to an unprecedented degree (Halligan, Mackintosh and Watson 1996, pp. 62-63). Some senior parliamentary officers, however, regarded this very differently, seeing it as merely another evolutionary step in scrutiny to which the APS leaders would need to become accustomed. In 2001, reflecting that '[t]he advent of broad-based committee systems in both the Senate and House of Representatives, has led to scrutiny being extended generally from Ministers to public servants', they emphasised that '[s]crutiny can be better exercised by committee members directing questions requiring in depth or detailed answers to public servants who may be more familiar with such details than Ministers' (Kerley and Harris 2001, p. 9).

Similarly, Max Trenorden stressed at this time that the traditional doctrine of accountability (the Westminster conception of a single chain of accountability via a minister) was essentially no longer valid, and that there now existed different levels and degrees of accountability following the landmark public service devolution and decentralisation of the late 1990s. However, as an MP himself, he acknowledged the difficulty confronting politicians in drawing the line when questioning public servants before committees, as they are increasingly involved in policy development and its review. Finding a balance 
between the accountability of public servants for administration and the political responsibility of ministers in the greatly altered public policy arena of the early 2000s will not be easy. An initiative that could assist in this is a revised set of guidelines governing public sector employees' appearance before committees in an attempt to better define their roles and responsibilities while at the same time (by means of reform of the standing orders) placing the main burden to respond to committee scrutiny on the shoulders of the minister (Trenorden 2001, p. 98; Holland 2002).

Despite the direction offered to advisers in the Prime Minister's Guide on Key Elements of Ministerial Responsibility and the Members of Parliament (Staff) Act 1984, the issue of the conduct of ministerial advisers continues to raise questions. The Senate Select Committee on a Certain Maritime Incident, which reported in August 2002 (see especially the section on 'Accountability and Ministerial Advisers', SSCCMI 2002, pp. 173-187) identified 'a serious accountability vacuum at the level of ministers' offices'. The fact that it had been denied access to the relevant key ministerial staff during its inquiry caused the select committee serious concern and led it to recommend a number of reforms to existing arrangements. These included the formulation of a code of conduct to better regulate the activities and ensure the greater accountability of such staff.

The inquiry prompted considerable debate about the ministerial staff system during 2003. Anne Tiernan and Patrick Weller, while acknowledging that the edifice had developed into 'an important political institution', nevertheless identified five important deficiencies in it: the system had outgrown the arrangements designed originally to support and control it; the framework was based on an outdated set of myths and assumptions; the absence of a clear and shared understanding of the respective roles of ministerial staff and public servants was undermining the quality of APS advice and support to ministers; a number of partisan practices had developed around the system which was reducing general and specialist knowledge of its structure and operations; and the critical weakness of present practices centred on the issue of the accountability of ministers for the conduct and performance of ministerial staff, and the overall lack of accountability of staff themselves. 'Ministerial staff', they concluded, 'are the black hole of the executive - unaccountable in theory as well as practice' (Tiernan and Weller 2003, pp. 3, 9, and passim).

Dr Michael Keating has suggested that a new stage in accountability has been reached; just as public servants are now accountable for their advice and actions more broadly than to their minister alone, ministerial advisers must also be subject to a formal accountability regime which fully reflects their new roles and responsibilities in government, and particularly in executive-APS interaction (Keating 2003, pp. 92-93). Ambitious prescriptions to this end have been put forward by both academic authorities and a parliamentary committee. Anne 
Tiernan and Patrick Weller advocate greater transparency through mandatory reporting about central elements of the system, improved monitoring of its performance, and devising clearer lines of responsibility for such staff (Tiernan and Weller 2003, p. 10). Megan Kimber, speaking in late 2004, called for a fresh setting out of the functions of and relationships between ministers, their staff and public servants (Kimber 2004). A welcome publication in this area is the Australian Public Service Commission's Supporting Ministers, Upholding the Values (APSC 2006).

The most ambitious recommended reforms, however, remain those put forward by the Senate Finance and Public Administration References Committee report on 'Staff employed under the Members of Parliament (Staff) Act 1984' (SFPARC 2003b). The Committee called, inter alia, for the government to make ministerial staff available to appear before parliamentary committees in certain (specified) circumstances; recommended that the government, in consultation with the Parliament, provide a framework for the appearance of such staff; argued that the Act be restructured so as to better define the different categories of ministerial office employment; called for improved record-keeping practices within ministers' offices; recommended that a code of conduct for ministerial staff be devised and implemented, with such a code for non-ministerial staff employed under the act to follow; and insisted on the need for better training of staff (SFPARC 2003b, pp. xix-xxiv). Similar calls appeared in the ALP's August 2004 machinery of government statement (Latham and Faulkner 2004, p. 7). In government, Senator John Faulkner tabled 'Code of Conduct for Ministerial Staff' on 26 June 2008. The code contained 21 clauses. Some of the obligations outlined included that all ministerial staff should declare any gifts or hospitality; have no other outside employment; be aware of the APS code of conduct; acknowledge that they do not have the power to direct APS staff or make decisions; and not knowingly provide false information (Special Minister of State 2008). Yet, the code did not require ministerial staff to be directly accountable or answer questions before Parliament. Indeed the subject continues to provoke contrasting interpretation. In 2002, the Clerk of the Senate, for example, rejected the claim that either in practice or in law, ministerial staff cannot be summoned to appear as witnesses before parliamentary committees because they have immunity from such calls arising from the immunity of their ministers (Evans 2002, p. 137). Yet, the Clerk of the House of Representatives asserts that ministers and/or their staff should not be called upon to appear before a house (or one of its committees) of which the Minister is not a member because this would constitute an infringement of privilege (Harris 2002, pp. 105-106).

It is still largely the case (as it was in 1989) that ' $[\mathrm{t}]$ he duty of the public servant is to assist ministers to fulfil their accountability obligations by providing full and accurate information to the Parliament about the factual and technical 
background to policies and their administration' (Prime Minister and Cabinet 1989 , p. 1). However, it cannot be denied that in doing so, and in their dealings with ministers, ministerial staff and parliamentary committees, public sector employees are now confronted with a more complex and demanding set of challenges than in the late 1980s. That having been said, the APS of today is much more aware of the need to reflect on questions of accountability and, as it has shown, to work with the government of the day (as well as academic and non-academic commentators) in developing processes designed to better address scrutiny demands.

The role of ministerial advisers and other such staff in APS-executive interaction has for some years received systematic attention in the Australian Public Service Commission's annual 'State of the Service' report. The detailed synopsis it contains of APS staff relationships with ministerial offices suggests a generally harmonious set of relationships (APSC 2005b, pp. 34-43). The main foundations of this seem to be trust and clarity about what is required of public servants in such interchange. The APS values and code of conduct have provided (and continue to provide) a solid basis for the former. In March 2006, in order to strengthen the latter, the Australian Public Service Commission (APSC) released Supporting Ministers, Upholding the Values.

\section{Conclusion}

Almost certainly the best way forward for parliamentary scrutiny inside the two houses lies in implementing the remainder of the 1982 Hayden reform proposals and in ensuring that they are observed. Among the most effective means of achieving this would be to reshape the offices of President and Speaker so as to give them greater powers over the conduct of Question Time (as in Britain, in the case of the Speaker). The three legislative (or chamber) scrutiny vehicles examined in this chapter (Questions without Notice, Questions on Notice and Matters of Public Importance) are clearly in need of some further reform. The administration of the current wave of reforms since September 2010 demonstrates that the extent and success of such change will depend largely on the preparedness of the executive and the opposition front bench to collaborate in devising and abiding by in good faith initiatives aimed at providing the presiding officers with greater real authority over parliamentary proceedings. Overseas experience shows that these vehicles would then function more effectively, resulting in improved parliamentary oversight of the public sector. Parliament's committees must also display a greater willingness to investigate all aspects of APS operations. Some improvement has occurred with the revitalisation of the House of Representatives committee system. 
However, further gains could be made as trends in this area indicate that such scrutiny is neither broad-ranging enough nor based on the recognition that investigations of key features of public administration should be conducted regularly so as to better discern trends and devise improvements in processes and practices. Even in instances where encouraging work of this kind is begun, it is often not carried through. The Senate Finance and Public Administration References Committee reference, 'Australian Public Service Employment Matters' (28 June 1999), for example, was not readopted on 21 March 2002, despite the production of one valuable report on the subject entitled 'Australian Workplace Agreements' (SFPARC 2000). The question of the degree to which committee report recommendations and findings are being noted by public servants is also relevant. While the practice whereby the government of the day provides formal and detailed responses to report recommendations remains central to effective public administration, another opportunity exists in this context for APS employees to enhance their policy and administrative skills, one suggested recently by the British House of Commons Public Administration Select Committee. In its report, 'Government by Inquiry' (UKPSCPA 2005), it extended the conception and well-established practice of government response regarding implementation or non-implementation of recommendations to one concerned with public sector learning, namely, measures designed to ensure that the lessons of committee inquiries are better absorbed by public servants in order to improve their capability.

Scope exists, too, for the ANAO to undertake more review and follow-up inquiries and to revisit areas of APS administration, such as the structure, role and functioning of the Senior Executive Service. The proliferating number of separate bodies in the Australian government (which ebbs and flows around the 1,000 mark) reinforces the need to build on the reforms emanating from the Uhrig Report (2004) on Australian Government statutory authority governance, and to preserve and strengthen the present budget accountability and financial management arrangements governing APS operations. Despite the undoubted challenges they pose for the long-dominant, traditional Westminster model of governance, which has had considerable difficulty absorbing them, Australia (like Britain) appears to have accepted that '[g]overnment cannot be fully explained without reference to special advisers' (Blick 2004, p. 314). More importantly, perhaps, politicians, public servants and commentators (academic and nonacademic) seem to have acknowledged that, the need for a finer definition of the special adviser system's principles and practice notwithstanding, the APS and the ministerial adviser have separate (albeit important and complementary) contributions to make to sound governance - contributions which need not conflict or adversely affect public sector efficiency or good government. 
The shortcomings of Australia's parliamentary scrutiny arrangements as they relate to APS administration, which have been explored in this chapter, should not obscure the real possibilities that exist for change; nor should they overshadow the strengths of the present system and the impressive repository of existing Australian practice and ideas that is available to be drawn on in pursuing fruitful reform. Much can also be learned from the political and public administration experience and scholarship of other parliamentary democracies. Successful constitutional change depends greatly on a historical perspective (University of London, School of Advanced Study/History of Parliament Trust 2005). The same can be said of attempts to reform the government sector. The 'Effective Scrutiny' project at the School of Public Policy's Constitution Unit at University College, London, for example, has produced valuable research and political blueprints for improving scrutiny based on both historical research and analyses of present administrative practice. Some of its findings would undoubtedly be applicable in Australia. The British diplomat and writer on international affairs, Sir Harold Nicolson, a civil servant of 20 years' standing, regarded the civil service as a stable and essential anchor of governance. It was, he proclaimed, nothing less than 'the flywheel of the state', a body whose continuity and flexibility as an 'organism' rather than a 'machine' made it an immensely useful instrument of governance (Nicolson 1940, p. 4; 1950, p. 787). The Australian public service, like its British counterpart, faces constant challenges. Nevertheless, there is no reason to doubt its capacity to respond positively to and to benefit from the essentially sound apparatus of parliamentary scrutiny to which it is now and will continue to be subject.

\section{References}

Aldons, M. 2000, 'Rating the Effectiveness of Parliamentary Committee Reports: The methodology', Legislative Studies (15)1, pp. 22-33.

Aldons, M. 2001, 'Rating the Effectiveness of Committee Reports: Some examples', Australasian Parliamentary Review (16)1, pp. 52-61.

Aldons, M. 2003, 'Evaluating Parliamentary Committees: Light at the end of the tunnel?', Australasian Parliamentary Review 18(1), pp. 79-95.

Aldred, K. 1981, 'Accountability to the Parliament by the Executive and the Public Service: The view from the Parliament', in Government Expenditure and Accountability: The Relationship between the Parliament and the Public Service in the 1980s, Joint Committee of Public Accounts Seminar, 16 May 1980, AGPS, Canberra, pp. 74-81.

ALP (Australian Labor Party) 2004, ALP Platform. 
ALP 2007, ALP Platform.

ANAO (Australian National Audit Office) 1990, 'Survey of Internal Audit in the Commonwealth Public Sector', Audit Report No. 6, (PP141/1990), AGPS, Canberra.

ANAO 1991a, 'Accountability off the Rails - National Rail Corporation Limited: Erosion of accountability to the Parliament', Audit Report No. 16, (PP308/1991), AGPS, Canberra.

ANAO 1991b, 'Implementation of Purchasing Reforms in the Australian Public Service', Audit Report No. 3, (PP185/1991), AGPS, Canberra.

ANAO 1995, 'Financial Management: Department of Veterans' Affairs', Performance Audit Report No. 7, (PP287/1995), AGPS, Canberra.

ANAO 1996, 'The Administration of the Australian National Training Authority', Performance Audit Report No. 2, (PP98/1996), AGPS, Canberra.

ANAO 2000, 'Survey of Fraud Control Arrangements in APS Agencies', Performance Audit Report No. 47, (PP122/2000), AGPS, Canberra.

ANAO 2002, 'Recordkeeping', Assurance and Control Assessment Audit Report No. 45, (PP250/2002), ANAO, Canberra.

ANAO 2003a, 'Absence Management in the Australian Public Service', Performance Audit Report No. 52, (PP126/2003), ANAO, Canberra.

ANAO 2003b, Administration of Staff Employed under the Members of Parliament (Staff) Act 1984: Department of Finance and Administration', Performance Audit Report No. 15, (PP410/2003), ANAO, Canberra.

ANAO 2003c, 'Annual Performance Reporting', Performance Audit Report No. 11, (PP342/2003), ANAO, Canberra.

ANAO 2004a, 'Financial Delegations for the Expenditure of Public Monies in FMA Agencies', Business Support Process Audit Report No. 42, (PP/2004), ANAO, Canberra.

ANAO 2004b, 'Performance Management in the Australian Public Service', Performance Audit Report No. 6, (PP/2004), ANAO, Canberra.

ANAO 2004c, 'The Senate Order for Departmental and Agency Contracts (Calendar Year 2003 Compliance)', Business Support Process Audit Report No. 10, (PP/2004), ANAO, Canberra. 
New Accountabilities, New Challenges

ANAO 2005a, 'A Financial Management Framework to Support Managers in the Department of Health and Ageing', Performance Audit Report No. 5, (PP/2005), ANAO, Canberra.

ANAO 2005b, 'The Management and Processing of Leave', Performance Audit Report No. 16, (PP/2005), ANAO, Canberra.

APSC (Australian Public Service Commission) 2003, ‘The Australian Experience of Public Sector Reform', APSC, Canberra.

APSC 2005a, 'Foundations of Governance in the Australian Public Service', APSC, Canberra.

APSC 2005b, 'State of the Service Report 2004-05', APSC, Canberra.

APSC 2006, 'Supporting Ministers, Upholding the Values', APSC, Canberra.

Bach, S. 2003, Platypus and Parliament: The Australian Senate in theory and practice, Department of the Senate, Canberra.

Bagehot, W. 1974, 'The Non-Legislative Functions of Parliament', in N. St JohnStevas (ed.), Collected Works, Vol. 6, The Economist, London, pp. 41-45.

Barrett, P. 2004, 'Profiling the ANAO', Address to the 2004 Program for Officials of South-East Asian Parliaments, The Australian National University. Available at: http://www.anao.gov.au/ /media/Uploads/Documents/address_to_ the_2004_program_for_officials_of_south\%20east_asian_parliamentsl.pdf.

Baxter, K. 2003, 'Governance and the Public Sector', in Current Issues in Public Sector Governance, University of Canberra, Canberra, pp. 57-67.

Blick, A. 2004, People Who Live in the Dark, Politico's, London.

Bungey, M. H. 1979, 'The Role and Responsibilities of the Public Works Committee', in Financial Administration: Parliamentary Scrutiny, Joint Committee of Public Accounts Seminar, 1 June 1979, Commonwealth Parliament, Canberra, pp. 47-57.

Cairns, K. M. 1979, 'Parliamentary Scrutiny: The practice', in Financial Administration: Parliamentary Scrutiny, Joint Committee of Public Accounts Seminar, 1 June 1979, Commonwealth Parliament, Canberra, pp. 32-47.

Challen, D. W. 2004, 'Towards a Single Set of Accounting Standards for the Public Sector', CPA Public Sector Congress Annual Research Lecture, 17 November. 
Coates, J. 1990, 'A Finance and Public Administration Perspective: Complementing the estimates scrutiny process', in Parliamentary Workshop on Senate Estimates Scrutiny of Government Finance and Expenditure, Canberra, 17 October 1989, Papers on Parliament No. 6, March, pp. 20-26.

Coghill, K. 2002, 'Question Time: Questionable questioning with few answers', Democratic Audit of Australia, Swinburne University of Technology. Available at: http://apo.org.au/research/question-time-questionable-questioning-fewanswers.

Coghill, K. 2004, 'Auditing the Independence of the Auditor-General', Paper presented to the Political Science Program, Research School of Social Sciences, The Australian National University, 11 February. Available at: http://www.researchgate.net/publication/237601993_AUDITING_THE_ INDEPENDENCE_OF_THE_AUDITOR-GENERAL.

Cole, R. W. 1980, 'Responsible Government and the Public Service', in P. Weller and D. Jaensch (eds), Responsible Government in Australia, Drummond Publishing, Richmond, pp. 168-177.

Cole, R. W. 1981, Accountability to the Parliament by the Executive and the Public Service: Alternative perspectives', in Government Expenditure and Accountability: The relationship between the Parliament and the public service in the 1980s, Joint Committee of Public Accounts Seminar, 16 May 1980, AGPS, Canberra, pp. 117-126.

Coleman, P. 1982, 'Parliament and the Administration in New South Wales and the Commonwealth', in J. R. Nethercote (ed.), Parliament and Bureaucracy: Parliamentary scrutiny of administration: Prospects and problems in the 1980s, Hale \& Iremonger, Sydney, pp. 93-100.

Connolly, D. M. 1979a, 'Opening Remarks', in Financial Administration: Parliamentary scrutiny, Joint Committee of Public Accounts Seminar, 1 June, Commonwealth Parliament, Canberra, pp. 1-12.

Connolly, D. M. 1979b, 'The Role and Responsibilities of the Public Accounts Committee', in Financial Administration: Parliamentary scrutiny, Joint Committee of Public Accounts Seminar, 1 June, Commonwealth Parliament, Canberra, pp. 76-87.

Davey, R. C. 1959, The Public Accounts Committee: Management Problems in Finance Branches, Public Service Board, Canberra. 
Evans, G. 1982, 'Scrutiny of the Executive by Parliamentary Committees', in J. R. Nethercote (ed.), Parliament and Bureaucracy: Parliamentary scrutiny of administration: Prospects and problems in the 1980s, Hale \& Iremonger, Sydney, pp.78-93.

Evans, H. 2002, 'The Parliamentary Power of Inquiry: Any limitations?', Australasian Parliamentary Review 17(2), pp. 131-140.

Faulkner, J. 2003, 'Balancing Government Effectiveness with Oversight and Scrutiny', Address to the Sydney Institute, 30 September. Available at: http://australianpolitics.com/news/2003/09/03-09-30b.shtml.

Finance and Administration, Department of 2002 'Commonwealth Procurement Guidelines and Best Practice Guidance’, February 2002.

Finance and Administration, Department of 2003, 'Confidentiality of Contractors' Commercial Information', February 2003.

Finance and Administration, Department of 2004, 'Commonwealth Procurement Guidelines', December 2004.

Financial Management Guidance Publication No. 3.

Fraser, J. 2005, 'Questions Farce-Tracked', The Australian, 10 August.

Friedmann, W. 1950, Principles of Australian Administrative Law, Melbourne University Press, Carlton.

Halligan, J., I. Mackintosh and H. Watson, 1996, The Australian Public Service: The view from the top, Coopers \& Lybrand and the Centre for Research in Public Sector Management, University of Canberra, Canberra.

Hamer, D. 2004, Can Responsible Government Survive in Australia?, 2nd ed., Department of the Senate, Canberra.

Hancock, I. 2004, The V.I.P. Affair, 1966-67: The causes, course and consequences of a ministerial and public service cover-up, Australasian Study of Parliament Group, Canberra.

Harris, I. 2002, 'Rights and Obligations of a Legislature in a Federal, Bicameral System', Australasian Parliamentary Review 17(2), pp. 97-111.

HCIO (House of Commons Information Office) 2005, 'Parliamentary Questions', Factsheet P1 Procedure Series.

Hogg, J. 2001, 'Senate Estimates Committees', Australasian Parliamentary Review 16(2), pp. 167-173. 
Holland, I. 2002, 'Accountability of Ministerial Staff?', Research Paper No. 19, 2001-02, Department of the Parliamentary Library, Canberra.

Holland, I. 2003, 'Is There Adequate Parliamentary Scrutiny of Government Contracts?', Department of the Parliamentary Library Research Note No. 38. Available at: http://parlinfo.aph.gov.au/parlInfo/search/display/display.w3p ;query $=\mathrm{Id} \% 3 \mathrm{~A} \% 22$ library $\% 2$ Fprspub\%2F6XF96\%22.

Holzheimer, R. 1973, Parliamentary Influence on the Efficiency of the Commonwealth Public Service, 1960-1964, The Royal Institute of Public Administration (Queensland Group), Brisbane.

House of Representatives 2010, 'Agreement for a Better Parliament: Parliamentary reform'. Available at: http://parlinfo.aph.gov.au/parlInfo/download/library/ jrnart/640272/upload_binary/640272.pdf;fileType=application\%2Fpdf\#sea rch $=\% 22$ library/jrnart $/ 640272 \% 22$.

House of Representatives, Standing Committee on Economics, Finance and Public Administration 2003, 'Review of the Reserve Bank of Australia Annual Report 2002', (PP 404/2003), Commonwealth of Australia, Canberra.

HRSCE (House of Representatives, Standing Committee on Expenditure) 1979, 'Parliament and Public Expenditure', AGPS, Canberra.

HRSCP (House of Representatives, Standing Committee on Procedure) 1993, 'About Time: Bills, questions and working hours', AGPS, Canberra.

House of Representatives 2011, 'Interim Report No. 1: Monitoring and review of procedural changes implemented in the 43rd Parliament', AGPS, Canberra.

House of Representatives 2012, 'Interim Report No. 3: The effectiveness of reforms to the House committee system', AGPS, Canberra.

House of Representatives Practice 1981, J. A. Pettifer (ed.), AGPS, Canberra.

House of Representatives Practice 1997, 3rd ed., L. M. Barlin (ed.), AGPS, Canberra.

House of Representatives Practice 2001, 4th ed., I. C. Harris (ed.), Department of the House of Representatives, Canberra.

House of Representatives Practice 2005, 5th ed., I. C. Harris (ed.), Department of the House of Representatives, Canberra.

Hume, L. J. 1963, 'Parliamentary Scrutiny and the Financial Documents', Public Administration 22(2), pp. 165-178. 
Indyk, M. 1980, 'Making Government Responsible: The role of parliamentary committees', in P. Weller and D. Jaensch (eds), Responsible Government in Australia, Drummond Publishing, Richmond, pp. 93-110.

Joint Committee on the Parliamentary Committee System 1976, 'A New Parliamentary Committee System', AGPS, Canberra.

Joint Committee on War Expenditure 1941, 'First Progress Report', Commonwealth Parliament.

Joint Select Committee on Public Accounts 1932, 'Report', Commonwealth Parliament.

Keating, M. 2003, 'In the Wake of "A Certain Maritime Incident": Ministerial advisers, departments and accountability', Australian Journal of Public Administration 62(3), pp. 92-98.

Keating, M. 2004, 'Developments in Australian Democracy and the Public Service', Address to 'Parliament, the People and the Public Service', Symposium of the Association of Professional Executives of the Public Service of Canada, Ottawa, October.

Kerley, M. and I. Harris 2001, 'Parliamentary Checks on the Executive', Address to the 'Commonwealth Workshop on Accountability, Scrutiny and Oversight', Canberra, 23-25 May.

Kimber, M. 2004, 'Ministerial Advisers: Guardians or usurpers of responsible government?', Paper presented to the Australasian Political Studies Association Conference, Adelaide, 29 September-1 October. Available at: http://www.adelaide.edu.au/apsa/docs_papers/Aust\%20Pol/Kimber.pdf.

Langmore, J. 1996, 'Parliamentarians, Econocrats, and the People', in J. Disney and J. R. Nethercote (eds), The House on Capital Hill: Parliament, politics and power in the national capital, The Federation Press, Annandale, pp. 81-105.

Latham, M. and C. Emerson 2004, 'A Truly Independent Public Service'. Policy announcement: Australian Labor Party.

Latham, M. and J. Faulkner 2004, 'Machinery of Government: The Labor approach'. Policy announcement: Australian Labor Party.

Lewis, C. and K. Coghill 2005, 'Surveying Research on Parliament and Parliamentary Oversight of the Public Sector', Australian Journal of Public Administration 64(1), pp. 62-68.

Lewis, S. 2005, 'Auditor Plea to PM on Cuts', The Australian, 8 March. 
Mackey, T. C. 1979, 'The Role and Responsibilities of the Senate Standing Committee on Finance and Government Operations', in Financial Administration: Parliamentary scrutiny, Joint Committee of Public Accounts Seminar, 1 June 1979, Commonwealth Parliament, Canberra, pp. 87-97.

Marsh, I. 2004, 'Time's Up for Party Politics', The Australian Financial Review, 26 November.

Morrison, Croxford, Chambers \& Associates, 'Dealing With and/or Appearing before Parliamentary Committees', Kingston, ACT.

Mulgan, R. 2003, Holding Power to Account: Accountability in modern democracies, Palgrave Macmillan, Basingstoke.

Murray, A. 2005, 'Will Government Control of the Senate Change its Relationship with the Public Service?', Paper presented at the National Institute for Governance Seminar, 'Public Sector Governance and the Senate', Parliament House, Canberra, 9 November.

National Institute for Governance 2005a, 'Public Sector Governance and the Senate', Seminar, Parliament House, Canberra, 9 November.

National Institute for Governance 2005b, 'Trust in the Public Sector', Seminar, Old Parliament House, Canberra, 4 August.

Nethercote, J. R. 2003, 'Australian Public Administration in Perspective', in The Australian Experience of Public Sector Reform, APSC, Canberra, pp. 11-21.

Nicolson, H. 1940, BBC Home Service Broadcast (Transcript), 18 December, p. 4.

Nicolson, H. 1950, 'Marginal Comment', The Spectator, 9 June.

Odgers, J. R. 1979, 'Parliamentary Scrutiny: The theory', in Financial Administration: Parliamentary scrutiny, Joint Committee of Public Accounts Seminar, 1 June, Commonwealth Parliament, Canberra, pp. 23-32.

Odgers, J. R. 2001, Odgers' Australian Senate Practice, 10th ed., H. Evans (ed.), Department of the Senate, Canberra.

O'Faircheallaigh, C., J. Wanna and P. Weller 1999, Public Sector Management in Australia: New challenges, new directions, 2nd ed., Macmillan, South Yarra.

Parliamentary Joint Committee of Public Accounts 1993, 'The Midford Paramount Case and Related Matters', Report No. 325 (PP 491/1992), AGPS, Canberra.

Parliamentary Library 1995, 'Accrual Accounting: A cultural change', Report No. 338 (PP 182/1995), AGPS, Canberra. 
Parliamentary Library 2011, 'Commonwealth Parliament: The first year', Department of Parliamentary Services, Canberra.

Parliamentary Joint Committee of Public Accounts and Audit 2000, 'Contract Management in the Australian Public Service', Report No. 379 (PP 456/2000), Commonwealth of Australia, Canberra.

Parliamentary Joint Committee of Public Accounts and Audit 2003a, 'Annual Report 2002-2003', Report No. 397 (PP 400/2003), Commonwealth of Australia, Canberra.

Parliamentary Joint Committee of Public Accounts and Audit 2003b, 'Review of Australia's Quarantine Function', Report No. 394 (PP 30/2003), Commonwealth of Australia, Canberra.

Parliamentary Joint Committee on Native Title and the Aboriginal and Torres Strait Islander Land Fund 2003, 'Effectiveness of the National Native Title Tribunal', (PP 434/2003), Department of the Senate, Canberra.

Prime Minister and Cabinet, Department of the 1989, 'Government Guidelines for Official Witnesses before Parliamentary Committees and Related Matters', Department of Prime Minister and Cabinet, Canberra.

RCAGA (Royal Commission on Australian Government Administration) 1976, 'Report', Chairman: H. C. Coombs, AGPS, Canberra.

Reid, G. S. 1981, 'Accountability to the Parliament by the Executive and the Public Service: An alternative view', in Government Expenditure and Accountability: The Relationship between the Parliament and the public service in the 1980s, Joint Committee of Public Accounts Seminar, 16 May 1980, AGPS, Canberra, pp. 126-136.

Reid, G. S. and M. Forrest 1989, Australia's Commonwealth Parliament 19011988: Ten perspectives, Melbourne University Press, Carlton.

Ryle, G. and L. Pryor 2005, 'The Inquiries that were Ignored', Sydney Morning Herald, 20 June.

Senate n.d., 'Procedures to be Observed by Senate Committees for the Protection of Witnesses'. Available at: http://www.aph.gov.au/Parliamentary_Business/ Committees/Senate/Procedures_to_be_observed.

Senate 1990, 'Senate Legislative and General Purpose Standing Committees: The first twenty years 1970-1990,' Senate Committee Office, Canberra. Available at: http://www.aph.gov.au/Parliamentary_Business/Committees/Senate/ Significant_Reports/first20years/contents. 
Senate 2001, 'Consolidated Register of Senate Committee Reports (1970-2004)', Senate Committee Office, Canberra.

Senate, Table Office, 1988, 'Parliamentary Privilege: Resolutions agreed to by the Senate on 25 February 1988', Senate Table Office, Canberra.

Senate Committee of Privileges 1999, 'Parliamentary Privilege: Precedents, procedures and practice in the Australian Senate 1966-1999: 76th Report', (PP / 1999), Department of the Senate, Canberra.

Senate Committee of Privileges 2002, 'Parliamentary Privilege: Precedents, procedures and practice in the Australian Senate 1996-2002: 107th Report', (PP 345/2002), Department of the Senate, Canberra.

Senate Legal and Constitutional Legislation Committee 2003, 'Senate Legislation Committees: Reports on the examination of annual reports: March 2003', (PP 56/2003), Department of the Senate, Canberra.

Senate Legal and Constitutional References Committee 2002, 'Inquiry into the Outsourcing of the Australian Customs Service's Information Technology', (PP 265/2002), Department of the Senate, Canberra.

Senate Select Committee on the Functions, Powers and Operation of the Australian Loan Council 1993, 'Third Report', (PP 449/1993), Department of the Senate, Canberra.

Senate Standing Committee on Finance and Public Administration 1988, 'NonStatutory Bodies: Further report' (PP 110/1988), AGPS, Canberra.

Senate Standing Committee on Finance and Public Administration 1989a, 'The Timeliness and Quality of Annual Reports', (PP 468/1989), AGPS, Canberra.

Senate Standing Committee on Finance and Public Administration 1989b, 'Government Companies and their Reporting Requirements', (PP 398/1989), AGPS, Canberra.

Senate Standing Committee on Finance and Public Administration 1990a, 'The Development of the Senior Executive Service', (PP 206/1990), AGPS, Canberra.

Senate Standing Committee on Finance and Public Administration 1990b, 'The Development of the Senior Executive Service: Performance Based Pay', (PP 3/1990), AGPS, Canberra.

Senate Standing Committee on Finance and Public Administration 1992, 'Management and Operations of the Department of Foreign Affairs and Trade', (PP 525/1992), Department of the Senate, Canberra. 
Senate Standing Committee on Finance and Public Administration 1993, 'Performance Pay' (PP 432/1993), Department of the Senate, Canberra.

SFPALC (Senate Finance and Public Administration Legislation Committee) 2000, 'The Format of the Portfolio Budget Statements: Third report', Department of the Senate, Canberra.

SFPALC 2003, 'Senate Legislation Committees: Reports on the examination of annual reports: September 2003', (PP 267/2003), Department of the Senate, Canberra.

SFPARC 1995a, 'Property Management in the Australian Public Service', (PP 150/1995), Department of the Senate, Canberra.

SFPARC 1995b, 'Service Delivery ... by the Australian Public Service', (PP 15/1996), AGPS, Canberra.

SFPARC 2000, 'Australian Public Service Employment Matters: First report: Australian workplace agreements' (PP/2000), Department of the Senate, Canberra.

SFPARC 2003a, 'Recruitment and Training in the Australian Public Service (APS)', (PP 200/2003), Department of the Senate, Canberra.

SFPARC 2003b, 'Staff Employed under the Members of Parliament (Staff) Act 1984', (PP/2003), Department of the Senate, Canberra.

Shergold, P. 2004, “'Lackeys, Careerists, Political Stooges"?: Personal reflections on the current status of public service leadership', Australian Journal of Political Science (63)4, pp. 3-13.

Shergold, P. 2005, Address to National Institute for Governance Seminar, 'Trust in the Public Sector', Old Parliament House, Canberra, 4 August.

Special Minister of State 2008, 'Code of Conduct for Ministerial Staff'. Available at: http://www.smos.gov.au/media/code_of_conduct.html.

SSCCMI (Senate Select Committee on a Certain Maritime Incident) 2002, 'Report', (PP 498/2002), Department of the Senate, Canberra.

Stewart, J. 2002, 'Public Sector Management', in J. Summers, D. Woodward and A. Parkin (eds), Government, Politics, Power and Policy in Australia, 7th ed., Longman, Frenchs Forest, pp. 67-89.

Tiernan, A. and P. Weller 2003, 'Ministerial Staff: A need for transparency and accountability?', Submission to the Senate Finance and Public Administration References Committee Inquiry into Members of Parliament Staff (MoPS). 
Available at: http://www.google.com.au/url?q=http://aphnew.aph.gov.au/ binaries/senate/committee/fapa_ctte/completed_inquiries/2002-04/mops/ submissions/sub04.doc\&sa =U\&ei=eDsJVJrWGYu8ugTh9oBg \&ved=0CBQQ FjAA\&sig2=Y2SJnUmn-TU6XrJDj8qCCw\&usg=AFQjCNHaVdQcAXCTtpG LQQ4FoB3BscSmMQ.

Tingle, L. 2004, 'Lobbyists Learn to Deal with the New Deck', The Australian Financial Review, 11 November.

Trenorden, M. 2001, 'Public Sector Attitudes to Parliamentary Committees: A chairman's view', Australasian Parliamentary Review 16(2), pp. 97-101.

Uhr, J. 1982, 'Parliament and Public Administration', in J. R. Nethercote (ed.), Parliament and Bureaucracy: Parliamentary scrutiny of administration: Prospects and problems in the 1980s, Hale \& Iremonger, Sydney, pp. 26-67.

Uhr, J. 1990, 'Public Expenditure and Parliamentary Accountability: The debatable role of Senate estimates committees', in Parliamentary Workshop on Senate Estimates Scrutiny of Government Finance and Expenditure, Canberra, 17 October 1989, Papers on Parliament No. 6, March, pp. 79-113.

Uhr, J. 2005, 'Gaita-aid', Australian Book Review 270, p. 11.

UKPSCPA (United Kingdom Parliament, Select Committee on Public Administration) 2005, 'Government by Inquiry', (HC 51-I), 3 February.

University of London, School of Advanced Study/History of Parliament Trust 2005, 'What are Senates for?', University College, London, School of Public Policy, The Constitution Unit. Documentation on 27 May 2005 conference held at the Senate House, University of London.

Verspaandonk, R. and I. Holland 2003, 'Changes in the Australian Public Service 1975-2003'. Available at: http://parlinfo.aph.gov.au/parlinfo/search/ display/display.w3p;query=Id\%3A\%22library\%2Fprspub\%2F1CI96\%22.

Wanna, J., C. Ryan and C. Ng 2001, From Accounting to Accountability: A centenary history of the Australian National Audit Office, Allen \& Unwin, Crows Nest. 
This text taken from New Accountabilities, New Challenges, edited by John Wanna, Evert A. Lindquist and Penelope Marshall, published 2015 by ANU Press, The Australian National University, Canberra, Australia. 